\title{
Boşama Hakkındaki Bir Hadisin Tahlili
}

\section{Analysis of a Hadith About Divorce}

\author{
Abdurrahman Ece ${ }^{\text {a,* }}$ \\ ${ }^{a}$ Dr. Öğr. Üyesi, Siirt Üniversitesi, İlahiyat Fakültesi, Hadis Bölümü, 56100, Siirt/Türkiye. \\ ORCID: 0000-0001-9755-789X
}

\section{MAKALE BİLGİSI}

Makale Geçmişi:

Başvuru tarihi: 05 Haziran 2017

Düzeltme tarihi: 21 Ekim 2017

Kabul tarihi: 26 Ekim 2017

\section{Anahtar Kelimeler:}

Talâk

İtaat

İbn Ömer

Boşama

\section{ARTICLE INFO}

Article history:

Received 05 June 2017

Received in revised form 21 October 2017

Accepted 26 October 2017

\section{Keywords:}

Talâk

Obedience

Ibn Omar

Divorce

\section{ÖZ}

Kur'an-1 Kerim'de Allah'a ibadet emredildikten sonra, anne babaya ihsânda bulunmak emredilmiş, ebeveyne "öf" diyerek surat asmak dahi yasaklanmıştır. Buna paralel olarak hadislerde de Allah'ın rızasının anne-babanın rızasında olduğu zikredilerek onlara itaatin ehemmiyeti dile getirilmiştir. Peki, anne babaya "talâk" yani boşama konusunda da itaat etmek gerekli midir? Bu makalede, babasının talebi üzerine Hz. Peygamber'in İbn Ömer'e "eşini boşa" dediği bir rivayet, tespit ve anlama bağlamında ele alınmıştır. Konu hakkında âlimlerin görüşleri de verildikten sonra rivayet farklı bir açıdan değerlendirilerek doğru anlaşılması amaçlanmıştır.

\section{Giriş}

Evlilik sadece bir-iki kişinin isteği ile kurulacak kadar basit bir akit olmadığı gibi evliliği sona erdiren talâk da bir-iki kişinin isteği doğrultusunda başvurulacak basit bir yol değildir. Ehemmiyetlerine binaen her iki konu da hadis ve fikıh kaynaklarında ayrı ana başlıklar altında ele alınmıştır. Evlilik, Allah'ın ayetlerde emrettiği (Nisâ 4/3; Nûr 24/32), Resûlullah'ın da sünneti olan (Ebû Dâvud, ty: Nikah, 4; Nesâî, 2001: Nikâh, 3; İbn Mâce, ty: Nikâh, 1-8), meşru sınırlar içinde neslin devamını sağlayan İslam'ın en önemli kurumlarından biridir. Bu kurum dinin önemli amaçlarının gerçekleşmesine katkı sağladığı gibi insanları, zina ve fuhuş gibi toplumların temelini sarsan, ahlakını, güven ve huzurunu bozan haramlardan da alıkoymaktadır.

Bu makalede ilk bakışta Resûlullah'ın (s.a.s.) boşamayı hafife aldığını akla getiren bir hadisin araştırılarak doğru anlaşılmasına katkı sağlanması amaçlanmıştır. Bunun için evvela hadisin ana temelini oluşturan "talâk" ifadesinin ayet ve hadislerde hangi anlamlarda kullanıldığı tespit edilmeye çalışılmıştır. Bunun için bütün kaynaklardan ziyade temel hadis kaynaklarına bakılmıştır. Talâk ifadesinin ne anlama geldiği konusunda tefsir ve şerhlerden de istifade edilmiştir. Hadisin geçtiği temel kaynaklar tespit edildikten sonra hadisin bir bütünlük içinde anlaşılmasını sağlamak ve varsa metinlerdeki farklılıkları görmek için metinler bir araya

\footnotetext{
* Sorumlu yazar/Corresponding author. e-posta: arahman1977@ hotmail.com
} 
getirilmiştir. Daha sonra hadisin senedi tespit edilerek sıhhat incelemesi yapılmıştır. Sened hakkında yapılan değerlendirmeden sonra kısmen metin tenkidine gidilmiş ve hadisin hangi bağlamda anlaşılması gerektiği konusunda vardığımız neticeyle makale sonuçlandırılmıştır.

\subsection{Ayet ve Hadislerde "Talâk" Kavramı}

Boşamanın Arapça dilindeki karşılığı talâktır. Sözlükte serbest bırakmak anlamına gelen talâk (İbrahim Mustafa, 2004: II/563) fikhî bir terimdir ve "nikâh akdini belirli bir lafiz ile derhal ya da gelecekte ortadan kaldırmak ve izale etmek" demektir (Erdoğan, 2010: 542; Acar, 2010: 496). Bu ifade gerek ayetlerde gerekse hadislerde genellikle terim anlamında kullanılmıştır (Bakara 2/228-232-236-237-241; Ahzâb 33/49; Tahrîm 65/5).

Misal olarak ayet-i kerimelerde; "Eğer boşamaya kesin karar vermişlerse, şüphesiz Allah hakkıyla işitendir, bilendir." (Bakara 2/227) "Ey peygamber! Kadınları boşamak istediğinizde, onları iddetlerini dikkate alarak (temizlik hâlinde) boşayın ve iddeti sayın..."(Talâk 65/1) buyurulmuştur. Bu ifade konunun ehemmiyetine binaen Kur'an'daki 65. sûreye isim olmuş, ale'l-ebvâb yazılan hadis kaynaklarında ve fikı kitaplarında da "kitâbu't-talâk" ana bölüm başlığ 1 olarak yerini almıştır (Fuâd Abdulbâkî, 1950: 543). Ayet ve hadislerde kelimenin İnfi'âl انطلق bab1 da kullanılmış ancak bu kullanımla boşama anlamı kastedilmemiştir (Kehf 18/71-74-77; Şuara 26/13; Sâd 36/6; Fetih 48/15; Kalem 68/23; Mürselât 77/29, 30). Değerlendirmeye çalıştığımı hadiste geçen طَّلّنْ ifadesi de siyak ve sibakından anlaşıldığı kadarıyla terim anlamda kullanılmıştır ve "Eşini boşa" manasına gelmektedir (Eroğlu, 1986: XXVIII/159-165). Şimdi Hz. Peygamberin İbn Ömer'e "Eşini boşa" dediği rivayet üzerindeki değerlendirmelere geçebiliriz.

\subsection{Rivayetin Geçtiği Kaynaklar ve Metin Farklılıkları}

Rivayet, birden çok hadis kaynağında geçmekte ve metinler karşılaştırıldığında aralarında az da olsa metin değişiklikleri görülmektedir. Hadisi daha iyi anlamak için rivayetin yer aldığı kaynaklara ve metinler arasındaki değişiklere temas etmenin yararlı olacağı kanaatindeyiz. Kronolojik sıraya göre hadisin geçtiği kaynaklar şunlardır.

Rivayetin yer aldığı ilk kaynak Ebû Dâvud et-Tayâlisî'nin (ö. 204) Müsned'idir. Rivayet şöyledir:

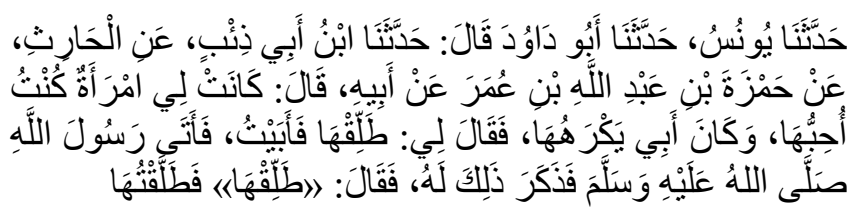

Yûnus bize anlattı. Ona da Ebû Dâvud anlattı ve dedi ki bize İbn Ebî Zi'b anlattı. O da el-Hâris'ten, o da Hamza b. Abdullâh b. Ömer'den, o da babasından rivayet etti. (Abdullah b. Ömer) Dedi ki: "Sevdiğim bir hanımım vardı. Babam onu sevmediği için bana, 'Onu boşa' dedi. Ben bundan kaçınınca babam Resûlullah'ın yanına gitti ve durumu ona anlattı. Bunun üzerine Resûlullah (s.a.s) bana: 'Onu boşa' dedi. Ben de boşadım." (et-Tayâlisî, 1999: III/363-364).

Rivayetin yer aldığı ikinci sıradaki kaynak İbn Ca'd'ın (ö. 230) Müsned 'idir. Rivayet şöyledir:

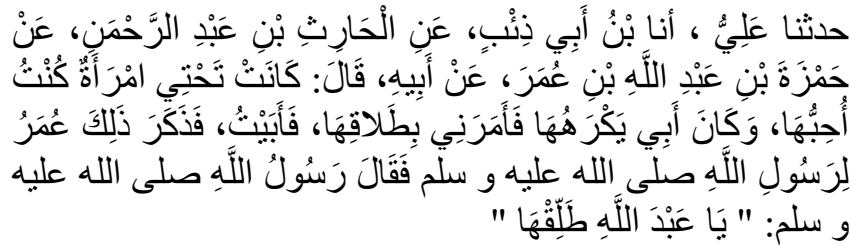

'Alî bize anlattı ve dedi ki, İbn Ebî Zi'b bize haber verdi. O da el-Hâris b. Abdurrahman'dan, o da Hamza b. Abdullah b. Ömer'tan, o ise babasından rivayetle dedi ki: "Sevdiğim bir eşim vardı. Babam ise ondan hoşlanmadığı için bana boşamamı emretti. Ben kabul etmeyince Ömer durumu Resûlullah'a anlattı. Allah Resûlü, "Ey Abdullah, o eşini boşa" dedi (İbn Ca'd, 1985: 989).

Rivâyetin yer aldığı üçüncü sıradaki kaynak Ahmed b. Hanbel'in (ö. 241) Müsned'idir. Eserdeki bir rivayet şöyledir:

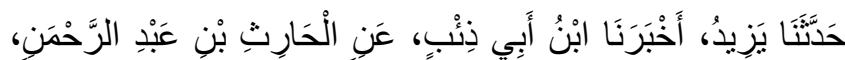

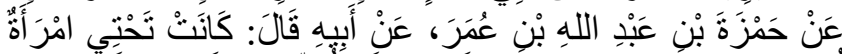

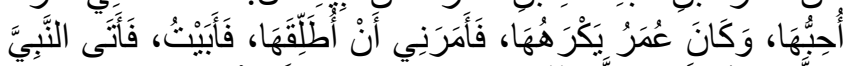

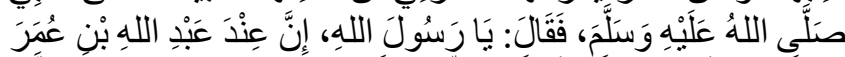

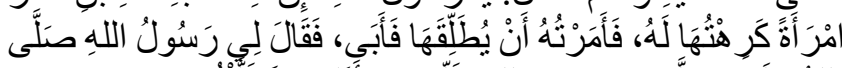

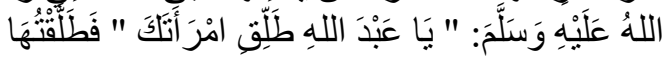

Yezîd bize anlattı dedi ki, İbn Ebî Zi’b bize haber verdi. O, el-Hâris b. Abdurrahman'dan, o Hamza b. Abdullah b. Ömer'den, o da babasından rivayetle dedi ki; "Sevdiğim bir eşim vard1. Babam ise ondan hoşlanmadığı için bana boşamamı emretti. Ben kabul etmeyince Allah Resûlü'ne "Ey Allah'ın Resulü, Abdullah b. Ömer'in nikâhında ona layı görmediğim bir kadın var. Bu nedenle de ondan bu kadını boşamasını emrettim. O ise kabul etmedi" dedi. Bunun üzerine Allah Resûlü, "Ey Abdullah, eşini boşa" dedi. Ben de boşadım.

$\mathrm{Bu}$ rivayette dikkatimizi çeken bir detay vardır. Hz. Ömer, durumu Resûlullah'a anlatırken, "Ey Allah'ın Resulü, Abdullah b. Ömer'in nikâhında ona layık görmediğim bir kadın var. $\mathrm{Bu}$ nedenle de ondan bu eşini boşamasını emrettim. O ise kabul etmedi" demektedir. Burada Hz.

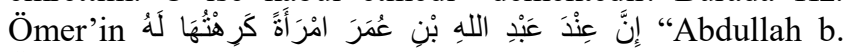
Ömer'in nikâhında kendisi için sevmediğim -uygun görmediğim- bir kadın var" ifadesi önemlidir (Ahmed b. Hanbel, 1999: IX/54). Burada Hz. Ömer'in niçin oğlundan eşini boşamasını istediği konusunda detaylı olmasa da bize fikir verecek bir ifade yer almaktadır. Bu ifadeden $\mathrm{Hz}$. Ömer'in oğlunun eşinden hoşlanmadığına dair bir ifade yoktur. Kanaatimizce o kadını kişiliği ile (takva, ahlak, şahsiyet vs.) İbn Ömer'e layık görmemektedir.

Ahmed b. Hanbel'in Müsned'inde yer alan diğer bir rivayette farklı bir detayın daha olduğunu görüyoruz. Buna göre Resûlullah (s.a.s.), Abdullah'ı çağırmış ve ona eşini boşamasını emretmiş o da eşini boşamıştır. Rivayette bunların tamamı açıkça zikredilmiştir. Bu rivayet aynı isnâd ve metin ile 'Abd b. Hümeyd'in ( ö. 249) Müsned'inde de yer almıştır. Rivayet şöyledir:

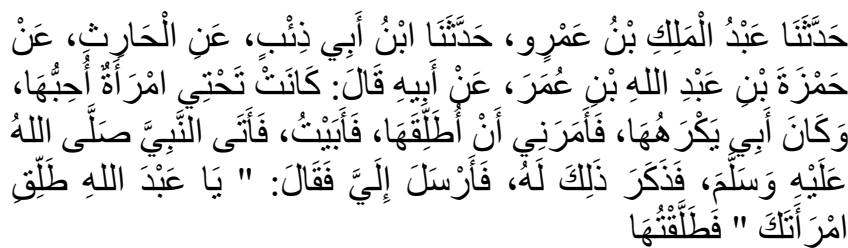


Abdülmelik b. 'Amr bize anlattı dedi ki, İbn Ebî Zi'b bize anlattı. O, el-Hâris'ten, o, Hamza b. Abdullah b. Ömer'den, o da babasından rivayetle dedi ki; "Sevdiğim bir eşim vardı. Babam ise ondan hoşlanmadığı için bana boşamamı emretti. Ben kabul etmeyince Allah Resûlü'ne bu durumu anlattı. Bunun üzerine Resûlullah (s.a.s.) bana yolladı ve "Ey Abdullah, eşini boşa" dedi. Ben de boşadım (Ahmed b. Hanbel, 1999: IX/143).

Müsned'teki diğer bir rivayette, Resûlullah (s.a.s.), Abdullah'1 çağırıp; فَقَالَ أَطِعْ أَبَالكَ "Babana İtaat Et” demekte, önceki rivayette verilen diğer detaylar ise zikredilmemektedir. Rivayet şöyledir:

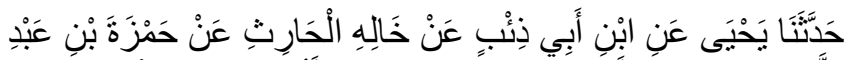

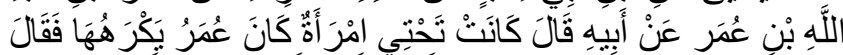

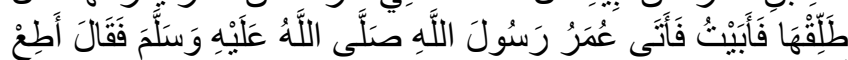

Yahyâ bize anlattı. O, İbn Ebî Zi'b'ten, o, el-Hâris'ten, o, Hamza b. Abdullah b. Ömer'den, o da babasından rivayetle dedi ki; "Benim sevdiğim ama babamın hoşlanmadığ 1 bir eşim vardı. Bana "onu boşa" dedi. Ben çekinince Ömer Resûlullah'a geldi. Resûlullah (s.a.s.) "Babana itaat et" dedi (Ahmed b. Hanbel, 1999: VIII/332-333).

Ahmed b. Hanbel'in verdiği dördüncü rivayette de lafiz farklılıkları göze çarpmaktadır. Burada da Hz. Ömer'in sevmediği için oğlu Abdullâh'tan eşini boşamasını istediği, oğlunun "Hayır" demesi üzerine, Ömer'in Hz. Peygambere haber verdiği ve bunun üzerine Resûlullâh'ın Abdullâh'1 çağırıp; "Eşini boşa" diye emrettiği ve Abdullâh'ın da eşini boşadığı anlatılmaktadır. Arapça metni şöyledir:

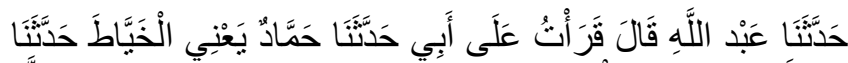

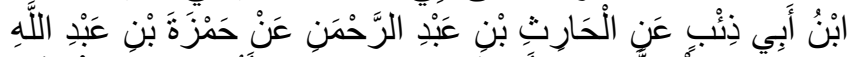

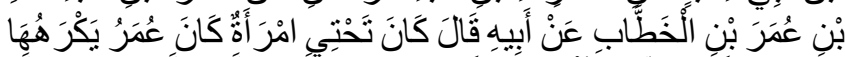

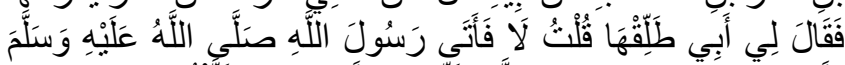

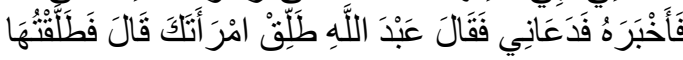

Abdullah dedi ki Kiraat yoluyla babamdan hadisi naklettim. Babam dedi ki bize Hammâd yani el-Hayyât anlattı. O da dedi ki bize İbn Ebî Zi'b anlattı. O, el-Hâris b. Abdurrahman'dan, o, Hamza b. Abdullah b. Ömer b. elHattâb'tan, o da babasından rivayetle dedi ki; "Babam Ömer'in hoşlanmadığ bir eşim vardı. Bana "onu boşa" dedi. Ben "hayır" dedim. O da Resûlullah'a gelerek ona haber verdi. Allah Resûlü beni çağırdı ve bana "Abdullah! Eşini boșa" dedi ve ben de onu boşadım (Ahmed b. Hanbel, 1999: X/492).

Ebû Dâvud (ö. 275)'un Sünen'inde de rivayetin lafizları kısmen değişikliklere uğramışsa da Hz. Peygamberin verdiği cevap aynıdır, rivayet şöyledir:

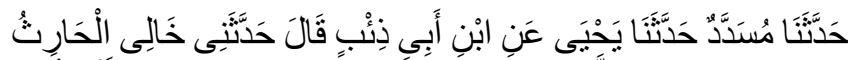

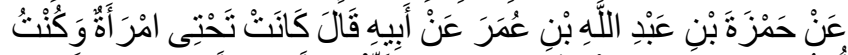

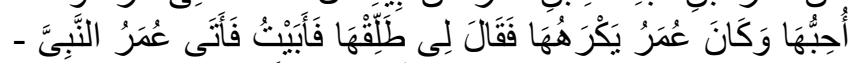

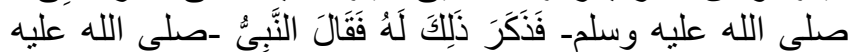

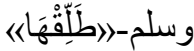

Müsedded bize anlattı, dedi ki bize Yahyâ anlattı. Yahyâ, İbn Ebî Zi'b'den rivayet etti. İbn Ebî Zi'b dedi ki bana dayım elHâris anlattı. O da Hamza b. Abdullâh b. Ömer'den, o da babasında rivayetle dedi ki: "Benim (nikâhım) altında sevdiğim bir kadın vardl. Ömer onu kerih gördüğü için benden onu boşamamı emretti. Ben onun emrini dinlemeyince gidip bu durumu Hz. Peygambere anlattı. Hz. Peygamber de bana: 'Onu boşa' dedi.” (Ebû Dâvud, ty: IV/499).

Tirmizî’nin (ö. 279) Câmi’inde yer alan aynı rivayetin metnine baktığımızda, anlama da etki eden değişikliklerin olduğu görülmektedir. Tirmizî'deki rivayet şöyledir:

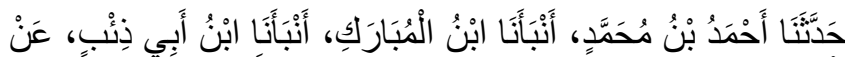

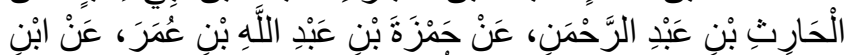

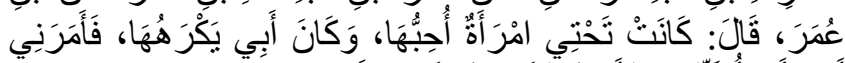

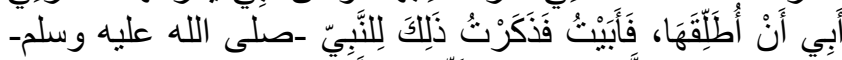

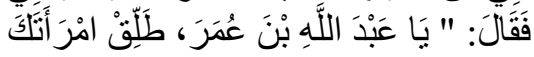

Ahmed b. Muhammed bize anlattı ve dedi ki; bize İbn elMübârek haber verdi. İbn el-Mübârek dedi ki; İbn Ebî Zi’b haber verdi. İbn Ebî Zi'b, el-Hâris b. Abdurrahman'dan, o Hamza b. Abdullâh b. Ömer'den, o da İbn Ömer'den rivayetle dedi ki: "Nikâhım altında sevdiğim bir kadın vardı. Babam ise onu sevmiyordu. Bana boşamamı emretti. Ben bundan kaçındım ve Hz. Peygamber'e durumu anlattım. Resûlullâh (s.a.s.): 'Ey Abdullah b. Ömer! Eşini boşa' dedi." (Tirmizî, ty: III/485).

Tirmizî hadisin sonunda, rivayetin sadece bir râvîden geldiğini ifade ederek: 'Bu rivayeti sadece İbn Ebî Zi'b'den gelen bir hadis olarak biliriz" demektedir. Ayrıca rivayetin sihhati konusunda da "حسن صحيح" "Hasenun sahîhun" ifadesini kullanmaktadır. Son dönem âlimlerinden Elbânî de rivayeti "Hasen” kabul etmiştir (Tirmizî, ty: III/485).

Dikkat edilirse geçen rivayetlerde yaşanan durumu Resûlullâh'a (s.a.s.) bildiren Hz. Ömer iken Tirmizî'nin rivayetinde oğlu Abdullâh b. Ömer'dir. Ayrica Hz. Peygamber ona, 'Ey Abdullah b. Ömer! Eşini boşa' diyerek ismiyle hitap etmekte ve eşini boşamasını emretmektedir. Tayâlisî'nin Müsned'i ile İbn Mâce'nin (ö. 273) Sünen'indeki rivayetlerde de İbn Ömer'in eşini boşadığı hususu yer almaktadır.

Aynı şekilde Elbânî’nin "Hasen” kabul ettiği ve İbn Mâce'nin Sünen 'inde yer alan rivayette durumu Resûlullah'a (s.a.s.) götürüp anlatanın Hz. Ömer olduğu açıkça zikredilmişken, durum karşısında Resûlullah'ın (s.a.s.) Hz. Ömer'e ne dediği zikredilmemiştir. Oysa Resûlullâh'ın (s.a.s.) ağzından çıkan ifade bizim için çok önemlidir. Zira o ifadeye göre biz bir şeyler konuşabiliriz. Oysa onun kavli yerine İ̉bn Ömer'in, "Resûlullâh (s.a.s.) bana eşimi boşamamı emretti ben de boşadım” ifadesi yer almıştır (İbn Mâce, ty: I/675). Bu değişiklik açık bir râvî tasarrufudur ve böylesi önemli bir konuda râvîlerin tasarrufa gitmesi kanaatimizce isabetli olmamıştır. Rivayet şöyledir:

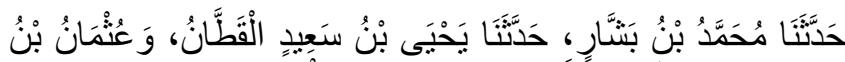

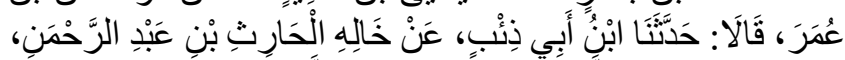

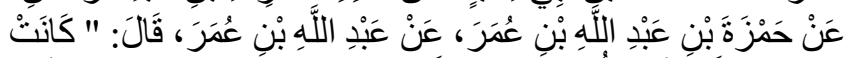

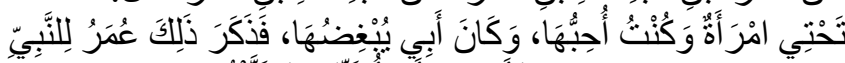

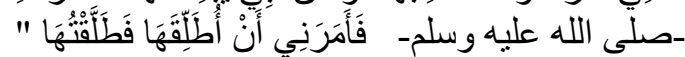

Hâkim'in el-Müstedrek'inde söz konusu rivayet iki yerde yer almakta ve her iki rivayette de tağyirler yani râvî tasarrufları göze çarpmaktadır. Rivayetlerde Hz. Ömer'in durumu gidip Resûlullah'a anlatış şekli detaylı anlatılmış, Resûlullah'ın 
cevâbî sözü "Ey Abdullah b. Ömer, Eșini boşa ve babana itaat et" diye verilmiştir. Rivayetlere göre Abdullâh da, "Ben de eşimi boşadım” demiştir. El-Müstedrek'teki birinci rivayet (Hâkim, ty: IV/153-154):

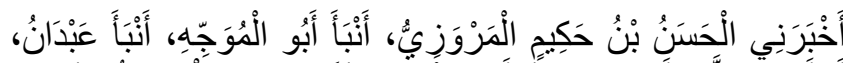

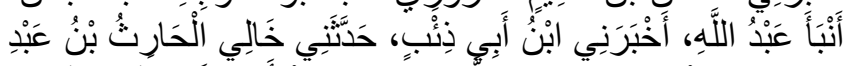

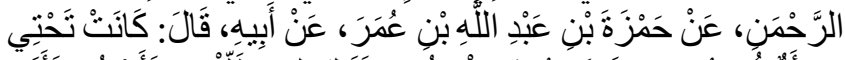

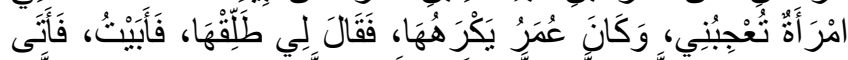

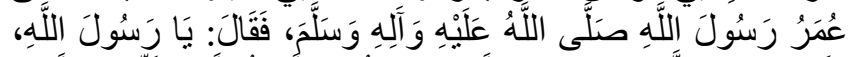

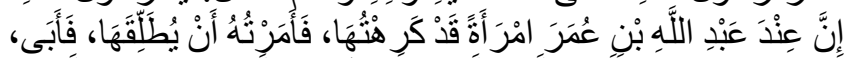

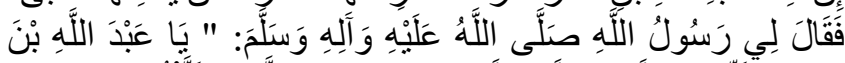

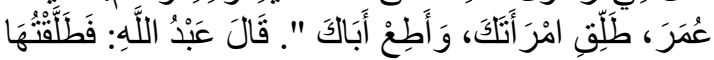

el-Müstedrek'teki diğer rivayet de şöyledir:

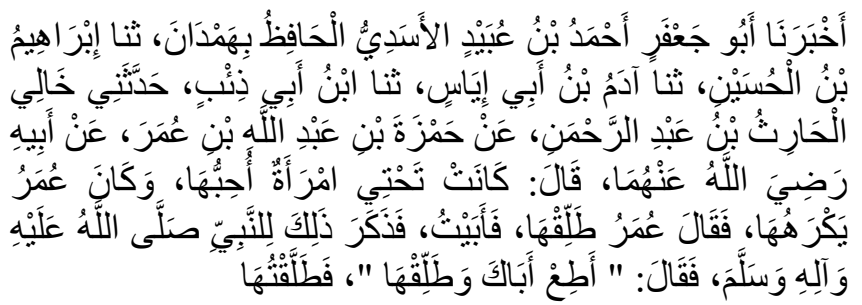

Hâkim'in bu rivayetler için yaptığı değerlendirmeler bizim için önemlidir. $\mathrm{O}$ bu rivayetler için şöyle demektedir. Birinci rivayet için;

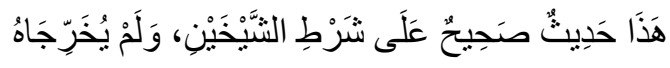

"Bu hadis Buhârî ve Müslim'in şartlarına göre sahîh bir hadistir. Fakat ikisi de bu hadisi kitaplarına almamıştır."

İkinci rivayet için;

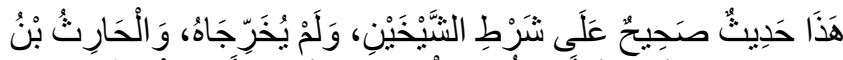

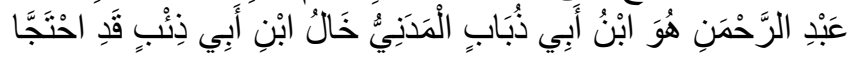

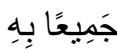

"Bu hadis Buhârî ve Müslim'in şartlarına göre sahîh bir hadistir. Fakat ikisi de bu hadisi kitaplarına almamıştır. Oysa ikisi (Buhârî ve Müslim) de İbn Eb̂̂ Zübâb elMedenî'in oğlu, El-Hâris b. Abdurrahman ile ihticâc etmişlerdir.(Rivayetlerini eserlerine almışlardır.)" (Hâkim, ty: II/197-198)

Rivayet İbn Hibbân'ın (ö. 354) Sahîh'i başta olmak üzere, Nesâî (ö. 303)'nin Sünenü'l-Kübrâ'sında (Nesâî, 2001: V/278), Taberânî'nin (ö. 360) el-Mu'cemu'l-Kebîr'i (Taberânî, 1983: XII/325) ve sonraki hadis kaynaklarımızda da yer almıştır. Şu'ayb el-Arnavût isnadını sahih olarak değerlendirmiştir (İbn Hibbân, 1993: II/170). Rivayet tek bir isnâd ile gelmiş ve daha sonra tariklere ayrılarak kaynaklara girmiştir.

Hz. Peygamber'in İbn Ömer'e söylediği çok kısa olan sözünde meydana gelen tağyirleri yani râvî tasarruflarını daha iyi görmek için kaynaklardaki hadis metinlerini Tablo 1 'de bir arada görelim.

Tablo 1'de görüldügü gibi az da olsa râvî tasarrufları göze çarpmaktadır. Kanaatimizce bu tağyirler mana ile rivayetten kaynaklanmıştır. Mana ile rivayet bir hadisin bütünlüğünü bozabilen tasarruflardan biridir. $\mathrm{Bu}$, genelde hadis rivayetinde uygulanan bir metottur (Coşkun, 2011: 37). Ancak âlimler, mana ile rivayete her hadis için cevaz vermemişlerdir (Coşkun, 2011: 37). Kanaatimizce bu hadis de mana ile rivayet edilebilecek bir hadis değildir. Aslında İbn Ömer de lafzen rivayete önem veren sahâbîlerin başında gelmektedir (Kandemir, 1988: I/127). Onun rivayeti lafzen yani Resûlullah'tan işittiği lafizlarla aynen rivayet ettiği kesindir. Ancak sonraki râvîler anladıklarını lafzen rivayet etmek yerine, kendi sözleriyle anladıkları şekilde vermişlerdir. Bir-iki kelimelik bir hadiste bu tağyirlerin olması, uzun hadislerde daha büyük tağyirlerin olma olasılığını akla getirmektedir. Bu itibarla hadislere anlam verilmeden önce metinlerde tağyirlerin olup olmadığının iyice araştırılması gerekmektedir.

Tablo 1. Hz. Peygamber'in İbn Ömer'e söylediği sözün kaynaklardaki metni.

\begin{tabular}{|c|c|}
\hline Kaynaklar & Metin ve Tercüme \\
\hline $\begin{array}{l}\text { Ebû Dâvud r et- } \\
\text { Teyâlisî (ö. 204), } \\
\text { Müsned, }\end{array}$ & "Onu boşa" dedi. \\
\hline $\begin{array}{l}\text { İbn Ca'd (ö. 230), } \\
\text { Müsned, }\end{array}$ & 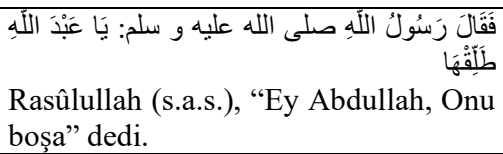 \\
\hline $\begin{array}{l}\text { Ahmed b. Hanbel (ö. } \\
\text { 241), Müsned, }\end{array}$ & 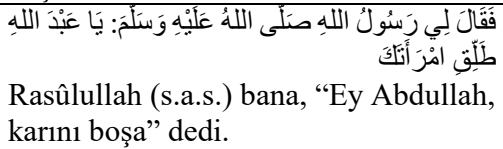 \\
\hline $\begin{array}{l}\text { Ahmed b. Hanbel, } \\
\text { Müsned, }\end{array}$ & 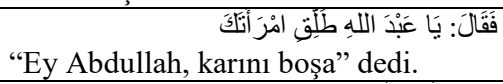 \\
\hline $\begin{array}{l}\text { Ahmed b. Hanbel, } \\
\text { Müsned, }\end{array}$ & "Babana itaat et" dedi. \\
\hline $\begin{array}{l}\text { Ebû Dâvud (ö. 275), } \\
\text { Sünen, }\end{array}$ & 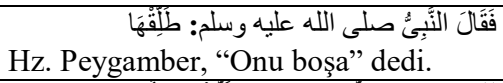 \\
\hline $\begin{array}{l}\text { Tirmizî } \quad(\ddot{o} . \\
\text { Câmi', }\end{array}$ & 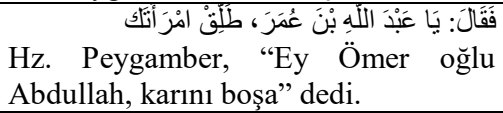 \\
\hline $\begin{array}{l}\text { İbn Mâce (ö. 275), } \\
\text { Sünen, }\end{array}$ & 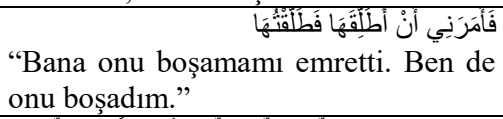 \\
\hline $\begin{array}{l}\text { Hâkim (ö. 405), } \\
\text { Müstedrek, }\end{array}$ & 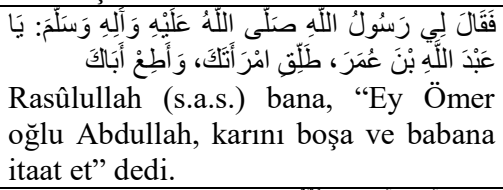 \\
\hline Hâkim, Müstedrek & 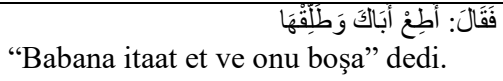 \\
\hline
\end{tabular}

\section{Hadisin Sıhhat Değerlendirmesi}

Bir hadis hakkında bir şeyler söyleyebilmek için evvela o hadisin makbûl olması yani merdûd bir rivayet olmaması gerekmektedir. Zira ancak makbûl bir hadis ile amel edilir. $\mathrm{Bu}$ itibarla rivayetin sihhat derecesini tespit etmek için evvela sened ve metin tenkidi yapılacak, hadisin nasıl anlaşılması gerektiği konusuna sonra değinilecektir.

\subsection{Hadisin Senedi}

Burada hadisin tüm kaynaklardaki senedlerini tek tek vermek makalenin sınırını aşacağından sadece yukarıda metinlerini de zikrettiğimiz erken dönem temel hadis kaynaklarımızdaki senedleri bir arada şema üzerinde verilecektir. 
Şekil 1. Hz. Peygamber'in İbn Ömer'e Söylediği Sözün Senedleri

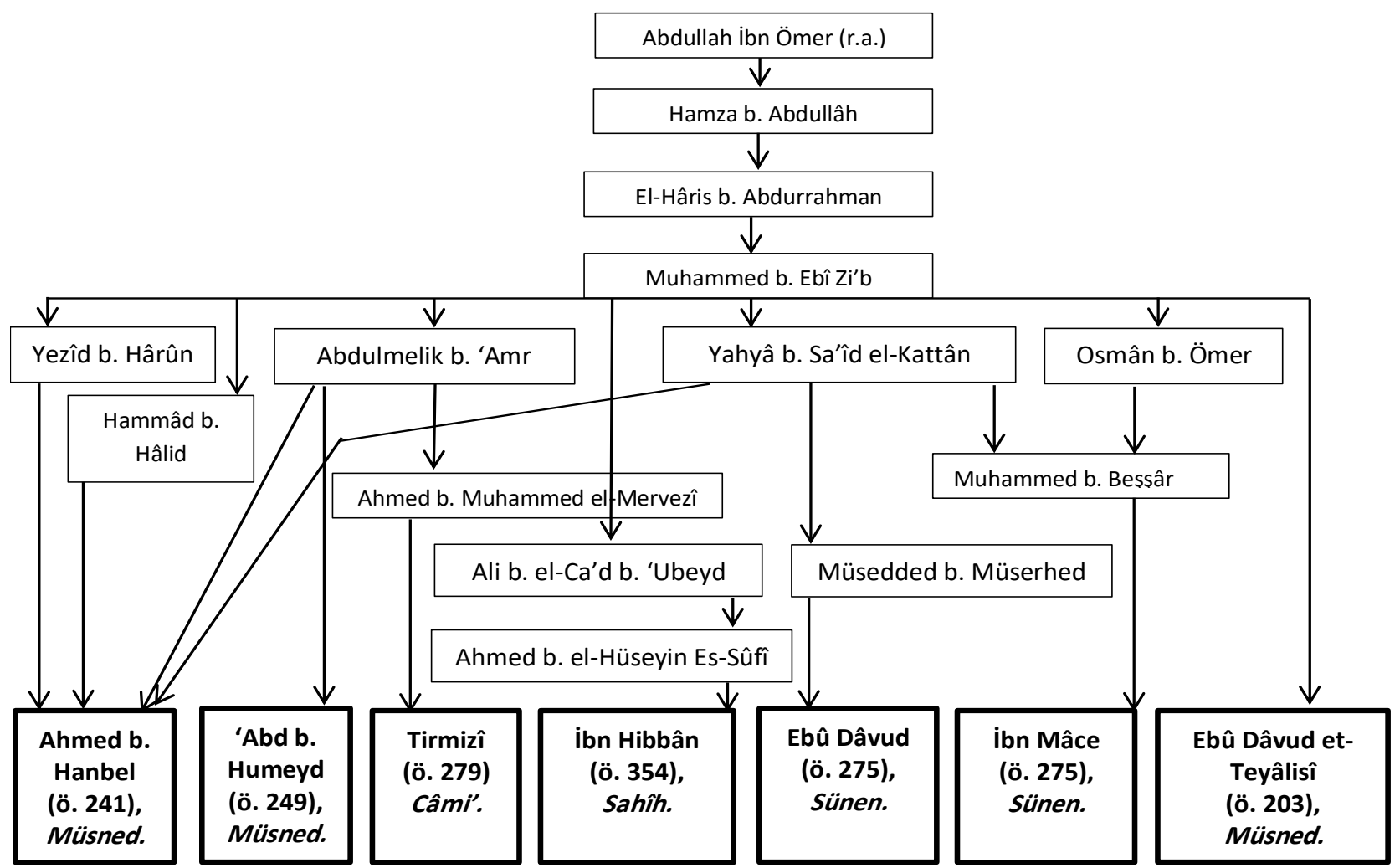

Şekil 1'de görüldüğü gibi rivayet Muhammed b. Ebî Zi'b'e (ö. 159) kadar tek bir senedle gelmiş ondan sonra tariklere ayrılmıştır. Dolayısıyla rivayetimiz aslında ferd bir rivayettir. Rivayetin girdiği ilk kaynaklar ise Ebû Dâvud etTeyâlisî'nin Müsned'i ile Ahmed b. Hanbel'in Müsned'idir. Şimdi cerh ve ta'dîl âlimlerinin bu senedlerde yer alan râvîler hakkındaki görüşlerine bakalım.

\subsubsection{Eb̂̂ Dâvud et-Teyâlisî'nin Müsned'indeki Rivayet}

Daha önce ifade edildiği gibi İbn Ömer'den gelen rivayetin, İbn Ebî Zi’b'e (ö. 159) kadar gelen senedi ferdi mutlaktır. Yani rivâyetin bütün kaynaklardaki senedi dördüncü râvî olan Muhammed b. Ebî Zi'b'e kadar müşterektir ve aynıdır. Rivâyet bu sened ile ilk müsned eser sayılan Ebû Dâvud etTeyâlisî'nin Müsned'ine girmiştir. Ebû Dâvud et-Teyâlisî dıșında dört râvî daha bu hadisi İbn Ebî zi'b'den almış ve kendilerinden sonraki râvîlere aktarmışlardır. Şimdi hadisin müşterek senedi olan bu kısımdaki râvîleri inceleyelim.

\subsubsection{Abdullâh b. Ömer}

Hadisimizin ilk ağızdan hem râvîsi hem de hadis içeriğini yaşayan kişi olan Abdullâh b. Ömer (r.a.) değerli bir sahâbîdir. İlim ve amelde İslam'ın mümtaz simâlarından biri olan Abdullah b. Ömer (r.a.) (ö.73), ikinci halife emîru'lmu'minîn Ömer b. Hattâb'ın oğludur. Resûlullah'ın eşi Hafsa'nın kardeşidir. Kendisi gibi genç sahâbîlerden biri olan Câbir b. Abdullâh (ö. 78) onu, "Aramızdan dünyaya hiç meyletmeyen tek kişi”" diye methetmiştir (Zehebî, 1998: I/37-40).

Dolayısıyla hadisimiz, Abdullah b. Ömer (r.a.) yönünden sahihtir ve olduğu gibi nakledilmiştir. Rivayetin gerek sened gerekse metniyle ilgili bir kusurdan söz edilecekse Abdullah b. Ömer (r.a.)'den sonraki ravilere bakılmalıdır. Abdullâh b. Ömer'in hadisleri çoğunlukla hizmetlisi Nâfi' tarafindan rivâyet edilmişken (Zehebî, 1998: I/99), bu rivâyet, Abdullah'ın oğlu Hamza'dan gelmektedir. Şimdi de cerh ve ta'dîl âlimlerinin Hamza b. Abdullâh hakkındaki görüşlerine bakalım.

\subsubsection{Hamza b. Abdullâh b. Ömer}

Tabiûnun orta tabakasından biri olan Hamza (ö. 101-110?), Abdullah b. Ömer'in oğlu Sâlim'in kardeşidir. Kütüb-i Sitte başta olmak üzere birçok hadis kaynağında rivâyetleri yer almıştır. Babası Abdullah b. Ömer, Hz. Aişe ve halası Hafsa'dan hadisler rivayet etmiş, ondan da başta İbn Ebî Zi'b'in dayısı el-Haris b. Abdurrahman olmak üzere birçok kişi hadis rivayet etmiştir. el-Mizzî (ö. 742), Hamza'nın hadislerinin çok olmadığını söylemektedir. el-'İclî’nin onu sıka kabul ettiğini ve İbn Hibbân'ın da onu "es-Sikât" adlı eserinde zikrettiğini söylemektedir. Ayrıca Yahya b. Sa'îd'in, “ Medine'nin on iki fakihi arasında onu da zikrettiğini” nakletmektedir (Buhârî, 1986: II/272; El-Mizzî, 1994: VII/330-vd).

Gerek rivayetlerinin sahih temel hadis kaynaklarında yar alıyor olması, gerekse cerh ve ta'dîl âlimlerinin onu sıka kabul etmesi, Hamza'nın adalet ve zabt sahibi birisi olduğunda bir şüphe bırakmamaktadır. Mevzu bahis olan hadisi de babasından aldığı için lika (hocası ile doğrudan buluşma) ve muâsaratta (aynı zaman diliminde yaşama) da bir sıkıntı yoktur. 


\subsubsection{El-Hâris b. Abdurrahman (El-Hâris b. Abdurrahman el-Kuraşî el-'Âmirî, Eb̂̂u Abdirrahmân el-Medenî)}

Yukarıda zikri geçtiği üzere el-Hâris b. Abdurrahman (ö. 127), Hamza b Abdullâh'ın talebelerinden biridir. Hamza'dan, kardeşi Sâlim b. Abdullah'tan ve daha birçok kişiden hadisler almıştır. İbn Ebî Zi'b'in dayısı olan elHâris'ten k1z kardeşinin oğlu Muhammed b. Abdurrahman b. Ebî Zi'b hadis rivayet etmiştir. Birçok âlim bunun dişında kimsenin ondan hadis rivayetinin olmadığını söylemiştir.

Nesâî, onun için "leyse bihî be'sun" -Ta'dîl'in dördüncü derecesini ifade eder. Genel olarak tevsik anlamına gelmektedir. Böyle râvîlerin hadisleri yazılır ancak sıhhati araştırılır (el-Minşâvî, 1996: 91), derken İbn Hibbân'ın da onu "es-Sikât" adlı eserinde zikretmiştir. Kutub-i Sitte'den Buhârî ve Muslim dışında kalan dört sünende de rivâyetleri yer almıştır (El-Mizzî, 1994: V/255-257). Sahabîlerle gazvelere de çıkmış olan el-Hâris, yetmiş üç yaşında hicri 127'de vefat etmiştir (İbn Hibbân, 1975: IV/134).

İbn Ebî Hâtım da İbn Ebî Zi'b’in dayısı el-Hâris’ten rivayetlerinin olduğunu zikretmiş ve Yahya b. Ma'în'in "Hadisleri rivayet edilir. O, meşhur biridir," dediğini ifade etmiştir (İbn Ebî Hâtım, III/80). İbn Hacer de onun için "sadûkun" -Birinci derece tavsîk ifadesi değildir. Kendisi için bu ifade kullanılan râvîlerin hadisleri sahih değil hasen kabul edilir. "Lâbe'se bihi" ifadesi ile aynı şeyi ifade eder (el-Minşâvî, 1996: 73)- ifadesini kullanmıştır (İbn Hacer, 1991: 146).

Netice olarak El-Hâris'in cerh ve ta'dîl âlimlerince cerh edilmemişse de tam tevsik de edilmemiştir. Ancak onun bu hadisi Hamza b. Abdullah'tan aldığına ve bunu Muhammed b. Ebî Zi'b'e aktardığına mani bir engel görünmemektedir. Yani tahammül ve edâ ile ilgili bir problem yoktur. Fakat kendisi için "sadûkun" ve "lâ be'se bihi" gibi ifadeler kullanıldığ 1 için rivayetleriyle hemen hüküm verilemez. Söz konusu rivayetleri, tam zabt edip etmediği araştırıldıktan sonra hüküm verilmelidir.

\subsubsection{Muhammed b. Ebî Zi'b (Muhammed b.} Abdurrahman b. el-Muğî̀re b. el-Hâris b. Ebî Zi'b elKuraşî el- 'Âmirî Ebû'l-Hâris el-Medenî)

Tebe-i tâbiînden biridir ve kader ile itham edilmiştir. İbn Ebî Zi'b (el-Cuzecânî, 1990: 319), hicri 80'de doğmuştur. Nâfi', İkrime ve başka tâbiîlerden rivayetleri vardır. Hicaz ve Iraklı eimme-i kibardan âlimler ondan rivayet etmişlerdir. İbn Hibbân onun için "Medine fakih ve abidlerinden biri idi ve hakkı söylemekten çekinmezdi ama kader fikrini savunurdu" demektedir. Hatta Mâlik b. Enes bunun için onunla konuşmazdı. Bağdat'a gitmiş oradan Medine'ye dönerken Kûfe'de 79 yaşında hicri 159'da vefat etmiştir (İbn Hibbân, 1993: VII/390-391; Nevevî, ty: 86).

Yahyâ b. Ma'în onu sıka kabul etmiştir. Alî İbn el- Medîni, Ebû Zur'a da onu sıka kabul etmişlerdir (İbn Ebî Hâtım, 1952: VII/314). Zehebî de onu methetmiş ve sıka kabul etmiştir (Zehebî, 1992: II/194). İbn Hacer de onun için "fakih ve sıka" demiştir (İbn Hacer, 1991: 493). Ahmed b. Hanbel onu Sa'îd b. Müseyyeb'e benzetmiş ve onun Mâlik b. Enes'ten takvaca daha üstün olduğunu lakin Malik kadar ricâl seçimine dikkat etmediğini söylemiştir (El-Mizzî, 1994: XXV/634). Sahîhayn'de rivayetleri vardır.
Kendisinden Süfyân-1 Sevrî, Yahyâ b. Sa'îd el-Kattân gibi önemli muhaddisler rivayette bulunmuşlardır (El-Kelâbâzî, 1987: II/662).

Görüldüğü gibi İbn Ebî Zi'b'in kaderle itham edilmiş olması, cerh sebebi olarak kabul görmemiş, Buhârî başta olmak üzere birçok hadis imâmı tarafından tevsîk edilmiştir.

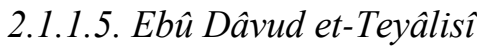

Süleyman b. Dâvud b. el-Cârûd Ebû Dâvud et-Teyâlisî (ö. 203) ilk müsned eser sahibidir. İbn Hibbân ile el-'İclî sıkâ râvîler arasında zikretmişlerdir (İbn Hibbân, 1975: VIII/275; el-'İclî, ty: I/427). Zehebî (ö. 748), Ebû Dâvud'un sıka ve hafiz bir hadis âlimi olduğunu, adaletine zarar verebilecek bir durum bilmediğini, hatta onun "otuz bin hadisi ezberden serdedebileceğini söylediğini aktarmıştır. Bununla birlikte İbrâhîm b. Sa'îd el-Cevherî onun için, bin kadar hadiste hata ettiğini söylerken (Zehebî, 1992: 103; Zehebî, 1992: 459; Zehebî, 1406: II/203), Ebû Hâtım, "çok hata ederdi" demiştir (Zehebî, ty: 401). İbn Hacer de onun kırk bin hadis hafızı ve sıka olduğunu ancak bazı hadislerde hata ettiğini zikretmiştir.

Buhârî rivayetlerine ta'lîklerinde yer verirken, Muslim ve dört sünen sahibi ise rivayetlerini almışlardır. Şu'be ve Süfyân-1 Sevrî gibi önemli râvîlerden hadis rivayet etmiş, ondan da Ahmed b. Hanbel, Alî el-Medînî gibi hadis imamları ve birçok kişi rivayet etmişlerdir (İbn Hacer, 1991: 250; İbn Hacer, 1995: IV, 161; Işık, 2008).

Öyleyse Ebû Dâvud et-Teyâlisî, her ne kadar cerh ve ta'dîl âlimleri tarafindan sıka kabul edilmişse de bir kısım hadislerde hata ettiği anlaşıldığından rivayetlerine ihtiyatla yaklaşılmalı, haklarında karar verilmeden önce başka râvîlerin rivayetlerine arz edilmelidir.

\subsubsection{Ahmed b. Hanbel'in Müsned'indeki Rivâyetler}

Rivayet, Ahmed b. Hanbel'in Müsned'ine dört tarikten girmiştir. Rivâyetin dört tarikinin de senedi İbn Ebî Zi'b'de birleşmektedir. Yani rivâyet tek sened ile İbn Ebî Zi'b'e kadar gelmiş o birçok talebesine anlatmıştır. Bunlardan biri yukarıda geçtiği gibi Ebû Dâvut et-Teyâlisî iken diğer dördü Yezîd b. Hârûn, Abdulmelik b. 'Amr, Yahyâ b. Sa'îd elKattân ve Hammâd b. Hâlid'tir. İște Ahmed b. Hanbel rivayeti, bu dördünden ayrı ayrı almıştır. Şimdi bu dört râvî'nin cerh ve ta'dîl durumuna bakalım.

\subsubsection{Yezîd b. Hârûn b. Zâzî Ebû Halid el-Vâsitî}

Etbâ-1 tabiînden ve Kütüb-i Sitte ravilerinden biri olan Yezîd b. Hârûn el-Vâsitî (ö. 206), birçok âlim tarafından sıka, hafız, imâmun fi'l-hadîs, sahîhu'l-hadîs ve mutkin gibi ta'dîl ifadeleriyle nitelendirilmiştir. Yahyâ b. Ma'în, Alî el-Medînî ve Ahmed b. Hanbel bunlardan bazılarıdır (İbn Ebî Hâtım, 1952: IX/295; İbn Hacer, 1995: XI/321). Kendisi, bir hadis dışında hiçbir zaman tedlîste bulunmadığını söylemiştir. Tedlîs yaptığı o rivayeti de 'Avn'den yaptığını ayrıca belirtmiş, daha sonra "keşke yapmasaydım” demiştir (İbn Hacer, ty: 27). Kendisinden hadis alanlar arasında bu rivayeti eserine alan Ahmed b. Hanbel de vardır ('Alâu'dîn, 1988: 376). Ayrıca İbn Hibbân el-Mecruhîn adlı eserinde para kazanma peşinde olan birisinin Yezîd b. Hârûn'un hazır olduğu bir mecliste onun adına rivayetler uydurduğunu da zikretmiştir (İbn Hibbân, 1992: I/86). Hadiste cerh ve ta'dîl 
ehliyetine sahip biri olduğu kaynaklardan anlaşılmaktadır (Buhârî, 1986: II/88; Zehebî, 1425: 111).

Bütün bu tevsiklerle beraber ömrünün sonunda gözlerini kaybettikten sonra rivayet ettiği hadislerde hatalar yaptığının ve tedlîste bulunduğunun iddia edilmiş olması mevzu bahis rivayeti kendisinden aldığı İbn Ebî Zi'b'in de önemli şeyhleri arasında sayılmamış olması bu rivâyetine mesafeli bakmamızı gerekli kılmaktadır ('Alâu'dîn, 1988: 376; İbn Hacer, 1995: XI/321).

\subsubsection{Abdulmelik b. 'Amr el-Kaysî Eb̂̂ 'Âmir el- Basrî}

Basra'lı olan Abdulmelik b. 'Amr el-Kaysî Ebû 'Âmir (ö. 205) dokuzuncu tabakadandır. Kütüb-i Sitte râvîlerindendir. İbn Ma'în'e göre sıkâ, Ebû Hâtım'a göre sadûk, Nesâî'ye göre sıka me'mun, el-'İclî’ye göre sıka, Zehebî’ye göre elimâmu'l-hâfız, İbn Hacer ve daha birçok alime göre de sıka biridir. Şu'be ve Alî b. Mubârek'ten semâ'1 vardır (Buhârî, 1986: V/425; İbn Hacer, 1991: 365; İbn Hacer, 1995: VI/363). İbn Hibbân da Sıkât'ında zikretmiştir. Kendisinden İshâk b. Râhuye ve Ahmed b. Hanbel gibi büyük hadis imamları ve daha birçok râvi hadis rivayet etmişlerdir (İbn Hibbân, 1975: VIII, 388; el-Mizzî, 1994: XVIII/365).

İbn Ebî Zi'b'den rivayetlerinin olduğu da kaynaklarımızda zikredildiğinden şu durumda onun Ahmed b. Hanbel'in Müsned 'ine geçen rivayetinin senedi İbn Ebî Zi'b hakkında verilen yukarıdaki bilgiler nedeniyle en azında hasen kabul edilmelidir.

\subsubsection{Yahyâ b. Sa'îd el-Kattân Ebû Sa'îd el-Basrî}

Lakabı el-Ahvel olan Yahyâ b. Sa'îd b. Ferrûh el-Kattân (ö. 198) hadis hafizlarındandır. İbn Hacer onun için birinci derece tevsîk ifadelerinden "sıka, mutkın, hâfız, imâm, kudve" ifadelerini kullanmaktadır. Hicrî 198'de 78 yaşında vefat etmiştir. Kütüb-i Sitte râvîlerindendir. İmâm Mâlik b. Enes, el-Evzâ'î, İbn Cüreyc, İbn Ebî 'Arûbe, Süfyân-1 Sevrî, Şu'be gibi birçok hadis imâmından hadis semâ'1 vardır. Kendisinden Ahmed b. Hanbel, İshâk b. Râhûye, Alî İbn elMedînî ve Yahyâ b. Ma'în gibi önde gelen muhaddisler ile kendi şeyhlerinden Şu'be, Süfyân-1 Sevrî, Süfyân b. 'Uyeyne ve akranlarından Abdurrahmân b. Mehdî ile Mu'temir b. Süleymân ve daha birçok kimse ondan rivayette bulunmuşlardır (İbn Hacer, 1991: 591; İbn Hacer, 1995: $\mathrm{XI} / 190)$.

Görüldüğü gibi Yahâ b. Sa'îd el-Kattân bütün hadis imamlarının ihticâc ettiği biridir. Bu itibarla onun rivayetleri de hüccet olarak kabul edilmiştir.

\subsubsection{Hammâd b. Hâlid el-Hayyât}

Kendisi Basra'lı olup sonradan Bağdat'a yerleşmiştir. Sahîhi Müslim ve Sünen-i Erbaa'da rivayetleri vardır (İbn Hacer, 1995: III/7). İbn Hibbân es-S1kât'ında zikretmiştir. Mâlik b. Enes ile İbn Ebî Zi'b'ten hadis rivayet etmiştir. Ondan da Ahmed b. Hanbel ile Iraklilar rivayette bulunmuştur (İbn Hibbân, 1975: VIII/206). Yahyâ b. Ma'în, Hammâd'ın ümmî biri olduğunu ancak sıka olduğunu söylemiştir. Ebû Hatım, "sâlihu'l-hadîstir, sıkadır" derken, Ebû Zur'a da "sıka bir şeyhtir" demiştir (İbn Ebî Hâtım, 1952: III/136). Ahmed b. Hanbel onun için "hafız biri idi, ben ve Yahyâ b. Ma'în ondan hadisler aldık" demektedir. Alî b. el-Medînî de s1ka olduğunu söylemiştir (İbn Hacer, 1995: III/7-8).

\subsubsection{Ahmed b. Hanbel (Ahmed b. Muhammed b. Hanbel eş-Şeybânî)}

Ahmed b. Hanbel, dört büyük imamdan biridir. Künyesi Ebû Abdillâh olan Ahmed b. Hanbel hadis rivayetinde sıka, hâfız, fakîh ve hüccet kabul edilmiştir. Hicrî 241'de 77 yaşında iken vefat etmiştir. Süfyân b. 'Uyeyne, Yahyâ b. Sa'îd elKattân, Ebû Dâvûd et-Teyâlisî, İmam eş-Şâfí'î gibi önemli kişilerden hadis rivayet etmiş, Buhârî ve Müslim gibi hadis imamları da ondan hadis rivayet etmişlerdir (İbn Hacer, 1995: I/62). Müsned onun bilinen en önemli eseridir.

\subsubsection{Diğer Raviler}

Tirmizî, Sünen'ine aldığı rivayeti Ahmed b. Muhammed b. Mûsâ el-Mervezî'den (ö. 235) almıştır. Ahmed b. Muhammed, Buhârî, Tirmizî ve Nesâî'nin kendisinden hadis aldıkları bir ravidir. Merdûye ismiyle bilinir. Cerh ve ta'dîldeki durumu "lâ be'se bih" yani birinci derecede olmasa da 'âdîl bir râvîdir (El-Mizzî, 1994: I/474).

İbn Hibbân'ın Sahîh'ine giren rivayetin senedinde Ali b. elCa'd b. 'Ubeyd, Ebû'l-Hüseyn el-Cevherî el-Bağdâdî (ö. 230) ile Ahmed b. el-Hüseyin Es-Sûfî (ö. 300'den sonra) bulunmaktadır. Ali b. el-Ca'd, Buhârî ve Ebû Dâvud'ta rivayetleri bulunan sıka ve sebt bir ravidir (İbn Hacer, 1991: 398). Ahmed b. el-Hüseyin Es-Sûfî'yi de el-Hâkim ve başkaları sıka kabul etmişlerdir. Bazı alimler ise rivayetlerinin sadece i’tibâr için alınabileceğini söylemişlerdir (Ez-Zehebî, ty: 76).

Ebû Dâvud'un rivayeti aldığı Müsedded b. Müserhed (ö. 228) el-Esedî el-Basrî de sıka ve hâfız bir ravidir. Basra'da yazılan ilk müsned eserin müellifi olduğu söylenmiştir. Buhârî, Ebû Dâvud, Tirmizî ve Nesâî'de rivayetleri vardır (İbn Hacer, 1991: 528).

İbn Mâce'nin rivayeti aldığı Muhammed b. Beşşâr el-Basrî (ö.252) ise onuncu tabakadan olup sıka kabul edilmiştir. Seksen küsur yaşında vefat etmiştir (İbn Hacer, 1991: 469).

\subsection{Sened Değerlendirmesi}

Ebû Dâvûd et-Teyâlisî'nin Müsnedi'ndeki rivayetin senedindeki râvilerin hiçbiri tedlis ile itham edilmemiş ve aralarında da hoca talebe ilişkisi sabittir. $\mathrm{Bu}$ durumda senetteki mu'an'an tahammül ve edâ siğaları rivayetin sihhatine etki etmemektedir. Ayrica rivayetin Ebû Dâvud etTeyâlisî'ye ulaşıncaya kadarki senette yer alan râvîlerden sadece el-Hâris b. Abdurrahman için "sadûkun" "lâ be'se bihi” gibi ifadelerin kullanıldığı görülmektedir. Ebû Dâvud için de "bazı hadislerde hata etmiştir" dendiği için rivayetin senedi sahih değil hasen kabul edilmelidir.

Haklarında cerh ve ta'dîl imamlarının görüşlerini zikrettiğimiz son dört râvî, İbn Ebî Zi'b'den bu rivayeti alarak Ahmed b. Hanbel'e nakleden kişilerdir. Dört râvinin de sıka olduğu, tevsiklerinde kayda değer herhangi bir olumsuz durumun olmadığı verilen bilgilerden anlaşılmaktadır. Nitekim Hammâd b. Hâlid el-Hayyât dışında, üç râvî Kutub-i Sitte râvilerindendir. Hammâd b. Hâlid de Müslim râvilerindendir.

Râviler arasındaki lika ve mu'âseratta da bir sıkıntı görülmemektedir. Rivayetin dayandığı İbn Ebî Zi'b'in dayısı olan El-Hâris b. Abdirrahman için "sadûkun", "leyse bihi be's'un" "yurvâ 'anhu” ifadeleri -bu ifadeler hakkında bilgi 
için (el-Minşâvî, 1996) bakılabilir- kullanılmıștır. Bu ifadelere göre el-Hâris'in rivayeti i'tibâr için yazılır ve başka tariklerden gelip gelmediği araştırılır. Dolayısıyla başka tariklerden gelmediği yani ferd olduğu anlaşılan bu rivayetin senedi sahih lizâtihi değildir. Öyleyse senedi için hasen diyebiliriz. Fakat rivayetin tamamı hakkında sağlıklı bir neticeye varmak için rivayeti metin yönünden de değerlendirmemiz gerekir.

\subsection{Metin Değerlendirmesi}

Rivayetleri bir araya getirdiğimizde ortaya şöyle ortak bir metin çıkmaktadır:

“İbn Ömer şöyle dedi. Benim sevdiğim ama babamın bana layık görmediği için sevmediği bir eşim vardl. Babam benden bu eşimi boşamamı istedi. Ben kabul etmedim. Babam da gidip durumu Allah'ın Resûlü'ne anlattı. Hz. Peygamber de beni çağırdı ve: "Ey Abdullah, babana itaat et ve o eşini boşa" dedi ben de o eşimi boşadım. "

$\mathrm{Bu}$ metne göre Hz. Ömer oğluna layık görmediği için oğlu Abdullah'tan eşini boşamasını istiyor. İbn Ömer itaat etmeyince Allah Resûlü'ne (s.a.s.) gidip durumu izah ediyor. Allah Resûlü de İbn Ömer'i çağırıp babası istediği için eşini boşamasını emrediyor ve İbn Ömer de Allah Resûlü'nün emrine itaat edip eşini boşuyor. Bu hadisten ilk etapta anlaşılan şey, kişinin sadece anne-babası istediği için eşini boşaması gerektiğidir. Peki, gerçekten öyle midir? Bunu doğru tespit etmek ve anlamak için konuyu Kur'an ve sahîh sünnet bütünlüğünde değerlendirip anlamamız gerekmektedir.

Ayetlerde kadınların hangi durumlarda boşanacağından ziyade boşamayı önleme tedbirleri, boşama sayısı ve sonrasındaki sürecin nasıl işleyeceği üzerinde durulmaktadır (Bakara 2/227-232, 236-237, 241; Ahzâb 33/49; Talâk 65/1; Tahrîm 65/5; Nisâ 4/34-35). Zira İslam'a göre evlilik bağ1, eşler arasında kurulan kutsal bir bağdır ve buna zarar verecek ya da bu bağı gevşetecek her türlü fiilden uzak durulması iki taraftan da istenmiştir. Nitekim Kur'an-1 Kerim'de eşler arasındaki nikâh akdi için ميثاقا غليظا yani "sağlam bir söz" olarak bahsedilmiştir (Nisâ 4/21). Dolayısıyla sahih bir nikâh akdi ile kurulan evlilik hayatı, İslam'ın 1srarla devam etmesini istediği ve bozulmasına karşı olduğu bir kurumdur.

Talâk, sadece evliliğin sürmesine imkân kalmadığında başvurulabilecek bir çözüm şekli olarak meşru sayılmıştır (Bakara 2/228-232-236-237-241; Talak 65/1-2; Buhârî, 1993: Talâk 1-4; Acar, 2010: XXXIX/496). Ayet-i kerimede erkeklerden eşleriyle iyi geçinmeleri talep edilmiş, nahoş hareketleri varsa sabretmeleri istenmiştir (Nisâ 4/19). Allah Resûlü de boşamaların önüne geçmek için iki tarafa da tavsiyelerde bulunmuştur (Ahmed b. Hanbel, 1999: XVI/114; Bezzâr, 2005: II/397; Tirmizî, 1962: Redâ', 11; İbn Mâce, ty: Nikâh, 50; İbn Hibbân, 1993: IX/483). Kadınlardan eşlerine itaat etmelerini, erkeklerden de eşlerine en iyi şekilde davranmalarını emretmiştir. Nitekim ayet-i kerimelerde böyle bir risk oluştuğunda evliliğin devam etmesi ve boşamayla sonuçlanmaması için, boşama yetkisi verilen erkeğin asî olan eşini hemen boşamaması, ilk etapta 1slah edici farklı yollara başvurması talep edilmiştir (Eroğlu, 1986: XXVIII/159-161). Hatta gerekirse iki aileden farklı hakemlerin arayı bulmak için uğraşmaları istenmiştir (Nisâ 4/34-35). Zira İslam'a göre nikâh akdi, belirli bir süre için değil, ömür boyu devam etmesi için kıyılmaktadır.
Her ne kadar İslam'ın cevaz verdiği bir konu olsa da haklı gerekçelere dayanmayan boşamaları Allah'ın sevmediği ve kul hakk1 olduğu anlaşılmaktadır (Kırbaşoğlu, 1991: 279). Zira kadınlar erkekler yanında kutsal bir emanet hükmünde kabul edilmiş, emanete sahip çıkmak ise emredilmiştir (Mu'minûn 23/8; Me'âric 70/32; Enfâl 8/27). Hadis-i Şeriflerde de emanete hiyanet nifak alameti olarak sayılmıştır (Buhârî, 1993: Îmân, 23). Her ne kadar başvurulacak son çare olarak boşamaya izin verilmişse de boşama, Allah'ın sevmediği bir fiil olarak ayrıca zikredilmiştir. Nitekim Hâkim en-Neysâbûrî’nin sahih kabul ettiği, Zehebî'nin Müslim'in şartlarını taşıdığını söylediği ve Ebû Dâvud'un Sünen'inde yer alan rivayette İbn Ömer (ö. 73), Resûlullâh'ın şöyle dediğini rivayet etmektedir: “Allah'ın, talâk kadar, sevmediği halde helal kıldiğ bir şey yoktur" (Ebû Dâvud, ty: Talâk 3; İbn Mâce, ty: Talâk 1; Hâkim, ty: II/214). Bu rivayet ile asıl konumuz olan rivayetin İbn Ömer'den geliyor olması dikkat çekicidir. Başka bir rivayette de Allah Resûlü: "Evlen, fakat boşanma, Zira Allah keyif için evlenip boşanan erkek ve kadınları sevmez" demektedir (Heysemî, 1994: IV/335).

Boşamanın Allah'ın razı olmadığı bir fiil olduğunu muhtemelen Hz. Ömer de bilmektedir. Bununla birlikte Hz. Ömer'in oğlundan eşini boşamasını talep ettiği ilgili rivayetten açıkça anlaşılmaktadır. Hâlbuki rivayetler, haklı bir gerekçe olmadığı sürece kocasından böyle bir talepte bulunma hakkını kadına dahi vermemiştir. Tirmizî'nin hasen kabul ettiği Elbânî'nin ise sahîh dediği birçok kaynakta yer alan bir rivayette Allah Resûlü (s.a.s.) şöyle demektedir: "Sebepsiz yere kocasından boşanmayı talep eden her kadına cennetin kokusu haramdır."( Ebû Dâvud, ty: Talâk 18; Tirmizî, 1962: Talâk 11; İbn Mâce, ty: Talâk, 21; İbn Hibbân, 1993: IX/490; Hâkim, ty: II/201). Hatta bu yola götürecek söz ve davranışlarda bulunanlar da kınanmıştır. Elbânî'nin sahîh dediği bir rivayette Allah Resûlü (s.a.s.): "Eşini kocasına karşı kışkırtan kişi bizden değildir" demektedir (Ahmed, 1999: XV/80, XXXVIII/82; Ebû Dâvud, ty: Talâk 1; Hâkim, ty: II/197).

Hem evlilik bağının devamı hem de boşamaların önüne geçmek için ayet ve hadisleri dikkate alan fukahâ talâk'ın hükmü konusunda farklı görüşler ortaya koymuşlardır. Kanaatimizce bunlar arasında en isabetli görüş Hanefiler ile Hanbelilerin sebepsiz yere boşamanın haram olduğu görüşüdür (Dalgın, 2009: 355; es-Seyyîd Sâbık, 1987: II/216). Sahih hadisler de bu görüşü desteklemektedir ki İslam'ın amacına uygun olan da budur. Evlilik nimet, keyfî talâk ise küfrân-1 nimettir. Küfrân-1 nimet ise haramdır. Haram olan bir şey ise zaruret olmadıkça helal olmaz. Allah, zevk için boşanan erkek ve kadınları sevmez (Bezzâr, 2005: VIII/70; Teberânî, 1985: VIII/24; İbn Ebî Şeybe, 2006: $\mathrm{X} / 189$ ). Ayrıca talâk ile evliliğin amacı olan neslin devamı ve birlikte yaşama gibi ana maslahatlar nihâyet bulduğundan iki taraf da zarar görmektedir (Acar, 2010: XXXIX/496). Arada çocuklar olduğunda zarar çok daha büyük olmaktadır. Bu da İslam'ın temel kaidelerinden biri haline gelen " لا ضرر "ISlam'da zarar vermek ve zarara zararla karşıllk vermek yoktur"'( Mâlik, 2004: IV/177; Ahmed, 1999: V/55; Şafiî, ty: 224; Hâkim, ty: II/58) sahih hadisine de muhâliftir.

İslam'ın talâk konusundaki emir ve tavsiyeleri bu kadar açık iken Hz. Ömer'in sadece sevmediği için oğlundan eşini boşamasını talep etmiş olması düşünülemez. Bir an için bunu yaptığını farz etsek bile Hz. Peygamber'in böyle haksız bir 
talebe onay vermesi mümkün değildir. Diğer önemli bir husus bu rivayetin bağlayıcılığı ile ilgilidir. Başka bir ifadeyle Sünnet'in bağlayıcılığı kapsamında bu hadisin nerede olması gerektiği ile ilgilidir. Bu konuda bir kanaate varmak için âlimlerin bu hadis hakkındaki görüşlerine geçmeden önce Sünnet'in bağlayıcılığı hakkında yapılan taksimata kısaca bakalım.

Sünnetin bağlayıcılığı ve getirdiği hükümler bakımından ilk taksimatı İbn Kuteybe (ö. 276) yapmış (Kardâvî, 2015: 48) ve hadisleri/sünnetleri a) Cebrâil'in Allah'tan alıp getirdikleri, b) Allah'ın Resûlullah'a görüş, ruhsat ve içtihat yapmak için izin verdikleri, -Bu alanda Allah Resûlü kişiye, mazerete ve duruma göre içtihatta bulunabilir- c) $\mathrm{Hz}$. Peygamber'in te'dîb amaçlı hadisleri (İbn Kuteybe, 1999: 283-286). İmam el-Karrâfî (ö. 684) de hadisleri bağlayıcılık açısından üçe ayırmaktadır. Ancak onun taksimatı biraz daha farklıdır. Ona göre Hz. Peygamber'in a) İmamet, b) Kazâ, c) Fetva/tebliğde bulunma olmak üzere üç yönü vardır (elKarrâfî, 2003: 426-432). Sünnetler bu üç kategoriye göre değerlendirilmelidir. İbn Kayyım el-Cevziyye (ö. 751) de Hz. Peygamber'in (.... كان هو الإمام، والحاكم، والمفتى، وهو الرسول) risâlet yanında, imamet, hâkimlik ve müftîlik görevlerinin olduğunu, sadece risâlet görevi alanına giren hadislerinin kıyamete kadar geçerli şer’i hükümler taşıdığını zikretmiştir (İbn Kayyım el-Cevziyye, 1994: III/489). Şah Veliyyullâh ed-Dihlevî (ö. 1176), konuyu daha kapsamlı değerlendirerek hadisleri, "Risâlet'in tebliği ile ilgili olanlar ve olmayanlar" diye bir ayırıma gitmiş ve sonra bunları dallandırmıştır. Yüce Allah'ın "Rasûl, size ne getirdiyse onu alın, sizi neyden sakındırdıysa da ondan uzak durun" (Haşr 59/7) ayetindeki emrinin Risâlet'in tebliği ile ilgili olanlar için olduğunu beyan etmiştir. İkinci kısım hadislerin ise Hz. Peygamber'in bir beşer olarak irâd buyurduğu Risâlet tebliği ile ilgili olmadıklarını iddia etmiştir (Ed-Dihlevî, 2005: I/223-224). Bunlar dışında Reşid Rıza, Şeyh Muhammed Şeltût ve Tahir b. Âşûr da bu konuda görüşlerini ortaya koymuşlardır (Karadâvî, 2015: 64-83). Hadislerin bu şekilde bağlayıcılık yönünden kısımlara bölünmüş olmasından açıkça anlaşılıyor ki, Resûlullâh'ın hadisleri bağlayıcılık cihetleriyle aynı derecede değillerdir. Onların bir kısmı belli şartlarda bazı hususları çözmeyi hedefleyen Resûlullah'ın devlet başkanlığı, idarecilik ve hâkimlik sıfatına mütealliktir. Bunlar umûmîlik ve devamlılık niteliği taşımamaktadır (Karadâvî, 2015: 84). Kanaatimizce Hz. Peygamber'in İbn Ömer'e eşini boşamasını istemesi olayı da bu hadisler kapsamda değerlendirilmelidir.

Âlimlerin bahsimize konu "boşama hadisi" hakkındaki görüşleri ise kısaca şöyledir. 'Ale'l-ebvâb hadis kaynaklarındaki konu başlıklarının genellikle müelliflerin konu hakkındaki görüşünü yansıttığı malumdur. Nitekim İmam Buhârî için söylenen " فقه البخاري في تراجمه " "Buhârî'nin fikhı bâb başlıklarındadır" "'Itr, 1997: 198) sözü bunu ifade etmektedir.

Ebû Dâvud, rivâyeti Kitâbu'l-Edeb bölümü altındaki "Bâbu Birri'l-Vâlideyn" alt başlık altında vermiştir (Ebû Dâvud, ty: Edeb, 130). Yani o rivayeti ana babaya itaat bağlamında anlamıştır. İbn Hibbân'da aynı görüştedir (İbn Hibbân, 1993: II/170). Tirmizî ise, Kitâbu't-Talâk bölümü altındaki "Babanın oğlundan eşini boşamasını istemesi" alt başlığı altında rivayeti zikretmiştir (Tirmizî, 1962: Talâk, 13). Bu onun, rivayeti talâk bağlamında anladığını ve babanın oğlundan eşini boşamasını isteyebileceği görüşünde olduğunu imâ ettirmektedir. İbn Mâce, Hâkim ve Beyhakî'nin de aynı görüşte oldukları anlaşılmaktadır (İbn Mâce, ty: Talâk, 36; Hâkim, ty: II/198; Beyhakî, 2003: VII/322). İbn Hibbân da "Evladın babasına itaati bağlamında Resûlullah'ın, İbn Ömer'den eşini boşamasını istemesi”" ifadesini rivayete başlik yaparak görüşünü ortaya koymuştur (İbn Hibbân, 1993: 170). Ahmed b. Hanbel'in Müsned'inin muhakkiki Şuayb el-Arnavud, es-Sindî’nin (ö. h. 1138) "Anne babanın boşama ile ilgili emirleri dine muvâfık ise, onlara itaatin nefsin arzularına göre hareket etmekten önce geleceği, hadisteki Resûlullah'ın "Babana itaat et" emrinden anlaşıldığını” söylediğini zikretmiştir (Ahmed b. Hanbel, 1999: VIII/333, 1 nolu dipnot).

Kastallânî (ö. h. 923), Şafî̂ fakîh İbnu'r-Rif'a'nın (ابن الرفعة) (ö. h. 710) oğlun babasının emriyle eşini boşamasını müstahâb talâktan saydığını söylemiştir (Kastallânî, 1323: VIII/127). Feydu'l-Kadîr müellifi el-Münâvî (ö. h. 1031) de İbn el-'Arâbî’nin "İlk oğluna eşini boşamasını söyleyenin Halîl İbrâhîm olduğunu, onun örnekliğinin yeterli olduğunu" söylediğini aktarmıştır (el-Münâvî, 1972: IV/346). Alî elKârî (ö. h. 1014) ise buradaki emrin duruma göre mendubiyet ya da vucûbiyet ifade edebileceğini söylemiştir (Alî el-Kârî, 2002: VII/3097). Görüldüğü gibi birçok âlim bu hadise dayanarak, babaya oğlundan eşini boşama hakkı ve yetkisi adeta vermektedir. Hatta Tahâvî (ö. h. 321), annenin evlatlar üzerindeki hakkının babanınkinden daha fazla olduğunu, böylesi durumlarda oğulların babalarının sözünü dinlemeleri gerektiği anlaşıldığını, babanın durumu bu ise annenin sözünü dinlemenin daha gerekli olduğunu ifade etmiştir. Ancak Tahâvî, buradaki boşamanın Allah'ın mubah kıldığ 1 durumlar için geçerli olduğunu, Allah'ın yasakladığı durumlar için ise geçerli olmadığını söyleyerek konuya biraz açıklık getirmiştir (Tahâvî, 1994: III/418). Bağavî (ö. h. 516) ise "Babanın oğlundan eşini boşamasını istemesi" başlığı altında rivayeti zikretmiş ancak açıklama yapmamıştır (Bağavî, 1983: IX/191).

İmam Gazâli İhyâ adlı meşhur eserinde gayet isabetli diyebileceğimiz ifadelere yer verdikten sonra, "Kişinin babası, eşinden hoşnut değilse o zaman da kişi eşini boşamalıdır" diyerek bu rivayeti kendine delil göstermiştir. İfadeleri şöyledir: "Her ne kadar talâk mubah k1lınmışsa da Allah'ın en sevmediği mubahlardandır. O da herhangi bir haksızlık söz konusu olmadığı zaman mubah olur. Haksızlık söz konusu ise mubah olmaz. Bunun için de mutlaka kadının suçlu olması gerekir. Zira Allah, “...Eğer itaat ederlerse, artık onların aleyhine başka bir yol aramayın..." (Nisâ 4/34) buyurmuştur. Yani boşamak için hilelere başvurmayın. Bir de eğer kişinin babası eşinden hoşnut değilse o zaman da kişi eşini boşamalıdır." Bunları aktardıktan sonra İbn Ömer rivayetini delil getirmektedir. Ancak "burada babanın Hz. Ömer gibi kötü bir maksadının olmaması gerekir" demektedir (Gazâlî, ty: II/335). İmam Gazâlî'nin bu ifadesi yerinde görülebilir. Ancak oğlundan böyle bir talepte bulunacak hiçbir babanın kendisini "kötü maksatlı" görmesi düşünülemez. Nitekim her anne-babanın âdil ve muttaki olduğunu söyleyemeyiz. Bazen oğullarıyla aralarında dünyevî bir kin ve düşmanlık da olabilmektedir. Öyleyse böylesi durumlarda her iki taraf da adalet ve hakkaniyete göre hareket etmelidir. Anne babanın haksız oldukları durumlarda oğul, âdîl davranarak tatlı bir dille anne babasına haksız olduklarını açıklayarak onları razı etme yoluna gitmelidir. Diğer taraftan haklı ve dinî bir husustan dolayı evlatlarından böyle bir talepte bulunan anne babaların 
talepleri değerlendirilmeli, yerinde görülen taleplerinde itaat etmek ve onları razı etmek tercih edilmelidir. Her hâlükârda adaletten ayrılmamak temel esas olmalıdır. Diğer bir ifadeyle mazlumun yanında olmak, zalimi de zulmünden alıkoymak amaç olmalıdır (Buhârî, 1995: Mezâlim, 5; Müslim, ty: Birr, 16).

Burada bize ufuk açacak bir açıklama da İbn Teymiyye'den gelmektedir: İbn Teymiyye’ye (ö. h. 728) "Çocukları olan birisine, annesi eşini sevmediği için ondan boşamasını isterse itaat etmesi gerekir mi?" diye sorulduğunda o, " Hayır, sadece annesi istediği için eşini boşaması helal değildir. Bilakis annesine iyilik etmesi gerekir. Fakat eşini boşaması iyilik kapsamına girmez" cevabını vermiştir (İbn Teymiye, 1987: III/331). Anne için durum böyle ise baba için de durumun aynı olduğu rahatlıkla söylenebilir.

İbn Ömer'le ilgili hadise tekrar dönersek şunu söylemenin doğru olacağı kanaatindeyiz. Burada İbn Ömer'den eşini boşamasını talep eden kişi, sıradan bir kişi değildir. Hz. Ömer, Ebû Bekir'dan (r.a.) sonra bu ümmetin en üstün insanı sayılan kişidir. Olaya bu cihetten bakan bilginler ise Resûlullâh'1n bu emrini Hz. Ömer'e has görmüşlerdir. Misal olarak Ezher âlimlerinden et-Tâcu'l-Câmi'u li'l-Usûl ve şerhi Ğâyetu'l-Me'mûl müellifi Mansûr Alî Nâsıf, "Bu durum, Ömer ve benzerlerine has bir şeydir" demiştir (Nâsıf, 1962: V/5,10 nolu dipnot). Buhârî’nin önemli şârihlerinden İbn Hacer'e göre ise Hz. Ömer, oğluna eşini boşamasını emretmekten ziyade, gidip Hz. Peygamber ile istişare etmiş, Hz. Peygamber de İbn Ömer'den eşini boşamasını istemiş o da emre itaat etmiştir (İbn Hacer, 1379: IX/360). Yani İbn Ömer, keyfi boşamanın Allah'ın sevmediği bir helal olduğunu herkesten daha çok bilmektedir. Bu sebeple de babasının boşama isteğini reddetmiştir. Buna göre İbn Ömer'in babasını reddetmesi, bir anlamda babanın 'boşanma talebine bir oğulun vereceği cevabın ne olabileceğine' dair şahsi içtihadı olarak görülebilir. Onu bu içtihattan vazgeçiren şey ise, Hz. Peygamberin talebidir.

Anne veya babanın haksız ve yerinde olmayan taleplerine itaat edilmeyeceği aslında sahih rivayetlerden açıça anlaşılmaktadır. Sahîh Sünnet'e göre İslam'a muhalif hiçbir konuda hiçbir kimseye itaat edilmez. Bu konuda sarîh birçok rivayet vardır (Buhârî, 1995: Ahkâm, 4; Muslim, ty: İmâre, 39; Ebû Dâvud, ty: Cihâd 96; Nesâî, 2001: Bey'at 34). Örnek babında bir tanesini burada zikretmenin yeterli olacağı kanaatindeyiz. Rivayet birçok temel hadis kaynağımızda yer almaktadır:

Hz. Ali diyor ki; Allah Resûlü, başlarına birisini komutan atadığı bir birliği sefere gönderdi. Bu birliğe komutanlarını dinleyip itaat etmelerini ayrıca tembihledi. Sonrasında komutanları bir ateş yaktı ve emrindekilere o ateşe atılmalarını emretti. Onlardan bir kısmı, "Biz, zaten ateşten kaçtık" diyerek ateşe atılmayı reddettiler. Bir kısmı da (Rasûlullah'ın emri için) ateşe atılmayı düşündüler. Bu haber Allah Resûlü'ne ulaşınca şöyle buyurdu: "Eğer onlar ateşe atılsalardı bir daha çıkmazlardl. Orada ebedi kalırlardı." Daha sonra, "Allah'a isyanda itaat yoktur. Sadece iyilikte itaat vardır" buyurdu (Buhârî, 1995: Ahkâm, 4; Muslim, ty: İmâre, 39; Ebû Dâvud, ty: Cihâd, 96).

Öyleyse burada Hz. Ömer'i talebinde haklı kılacak bir sebep mutlaka vardır. İbn Hacer'in dediği gibi burada Hz. Ömer'in Resûlullah ile istişaresi de söz konusudur. Zira Hz. Ömer'in oğluyla ilgili önemli ve yanlış gördüğü ya da tasvip etmediği durumları Resûlullah'a götürdüğü başka rivayetlerden de anlaşılmaktadır. Örneğin bir rivayette İbn Ömer şöyle demektedir: "Resûlullah'ın hayatında eşimi hayızlı/ayhalinde iken boşadım. Hz. Ömer bunu Resûlullah'a haber verdi. Resûlullah bu duruma kızd ve "Onu geri alsın, sonra hayzını görüp temizlemesini bekletsin. Eğer boşamak isterse temizlik halinde, onunla ilişkiye girmeden boşasın. İdet bekleyen kadınların boşamast, Allah'ın indirdiğ $i$ hükme göre böyledir..." (Müslim, ty: Talâk, 3; Nesâî, 2001: Talâk, 76) Dolayısıyla Hz. Ömer, oğlunun eşini boşamasını gerektirecek hususları bildiği için, bunlardan hareketle ona evvela "eşini boşa" demiş ve bir içtihatta bulunmuştur. Hz. Ömer'in hükümlerine son derece bağlı olan İbn Ömer ise içtihadına uymadığı için babasına muhalefet etmekten çekinmemiştir (Kandemir, 1988: I/127). Fakat Kur'an-1 Kerim, inananların ihtilafa düştükleri konularda Allah ve Resûlü'nün hakemliğine başvurmalarını emrettiği için (Nisâ 4/59-65) Hz. Ömer konuyu derhal Allah'in Resûlü'ne götürmüş ve konu orada çözülmüştür. Hz. Peygamber aynı zamanda davaları hükme bağlayan bir hâkim ve kâdıdır. Geçerli sebepler olması halinde hâkim de eşleri ayırabilmektedir (Acar, 2010: XXXIX/497). Burada Resûlullah'ın bir hâkem olarak durumu Hz. Ömer'den detaylıca dinledikten sonra İbn Ömer'i çağırdığı ve onu da dinledikten sonra "Eşini boşa" dediği kanaatindeyiz.

Başka bir ifadeyle Allah Resûlü bu hükmü, İbn Ömer'in babasına itaat etmesi bağlamında ya da Hz. Ömer'e has bir hüküm olarak vermemiş, bir devlet kâdısı olarak vermiştir. Rivayetin metinleri bütüncül değerlendirildiğinde bu kanaate varmak zor değildir. Zira ilk kaynaklarda ve birçok kaynakta yer alan hadis metninde Resûlullah'1n İbn Ömer'e "Eşini boşa" dediği, fakat "babana itaat et" demediği görülmektedir. Bu rivayetteki "babana itaat et" cümlesinin sonraki ravilerin bir idrâcı olduğu, ya da mana ile rivayetten kaynaklandığı kuvvetle muhtemeldir. Dolayısıyla bu rivayeti ebeveyne itaat bağlamında değerlendirmeleri isabetli değildir. Zira böyle bir değerlendirme birçok itaatkâr evladın sevdiği eşlerini hiçbir suçları olmadığı halde anne-babalarına itaatsizlik günahına düşmemek için boşamalarına yol açacağı ortadadır. Oysa bir günahın altına girmemek için bunu yapacak evlatlar, belki de bu tasarruflarıyla daha büyük bir günahın altına gireceklerdir. Dolayısıyla doğru olan İbn Teymiyye'nin de dediği gibi boşama konusunu anne babaya yapılacak iyilik kapsamında değerlendirmemektir. Anne babaya iyilik kapsamı geniş bir konudur. Lakin boşama da İslam'ın geniş kapsamlı ele aldığı hayatî bir konudur. Sahîh ve doğru olan, konuları yerli yerine koyarak değerlendirmek birbirine karıştırmamaktır.

Bu konuda Ebû'd-Derdâ'nın (r.a.) verdiği cevap söylediklerimizi teyid edecek mahiyettedir. Tirmizî’nin sahih dediği rivayete göre Ebû'd-Derdâ'nın yanına bir adam geliyor, "Benim bir eşim var ve annem benden onu boşamamı istiyor” diyor. Ebu'd-Derdâ ona diyor ki; “Annebaba, cennetin en iyi kapısıdır. Bu kapıyı istersen elinden çıkar, istersen de muhafaza et." (Tirmizî, 1962: el-Bir ve'sS1la, 3; İbn Mâce, ty: Talâk, 36) Burada Ebû'-Derdâ annebabaya itaatin önemini vurgularken soru soran kişiyi iyi düşünüp doğru karar vermeye teşvik etmektedir. Yani annebaban taleplerinde haklı iseler onların rızası kişiye cennetin en güzel yerini kazandırabileceği gibi, itaatsizlikleri de orayı kaybettirebilir. Ancak Ebû'd-Derdâ'nın burada Allah Resûlü'nin İbn Ömer'e dediği gibi adama “eşini boşa” ya da "boşama" gibi bir karar vermemesi dikkat çekicidir. Zira o 
kararı verebilecek kişi eşinin durumunu en iyi bilen kocası ya da davanın götürüleceği meşrû’ devlet kâdısı/hâkimidir. Böylesi hayatî konuları herkesin hâkime götürmesi de doğru değildir. Ya birebir davanın iki tarafında biri -karı ya da koca- olmalı ya da birinci derecedeki anne-babaları olmalidir.

Söz konusu hadisimizde konuyu Rasûlullah'a (s.a.s.) götüren kişi, İbn Ömer'in babasıdır. Hz. Ömer, oğluyla anlaşamadığı bu konu hakkında Rasûlullah'ın (s.a.s) hakemliğine başvurmakla isabetli bir yol izlediği gibi, İbn Ömer (r.a.) de Rasûlullah'ın verdiği hükmü kabul ederek isabetli davranmıştır. Baba ve oğul olarak ikisinin bu doğru davranışlarının arka planında, Rasûlullah'ın (s.a.s.) hakemliğine başvurmayı ve verdiği hükümleri gönül hoşnutluğuyla kabul etmeyi emreden ayetlerin olduğu kanaatindeyiz. Nitekim Allah (c.c.), Kur'an-1 Kerim'de şöyle buyurmaktadır:

“... Herhangi bir hususta anlaşmazliğa düştüğünüz takdirde, Allah'a ve ahiret gününe gerçekten inanıyorsanız, onu Allah ve Resûlüne arz edin. Bu, daha iyidir, sonuç bakımından da daha güzeldir.” (Nisâ 4/59).

"Hayır! Rabbine andolsun ki onlar, aralarında çıkan çekişmeli işlerde seni hakem kulıp, sonra da verdiğin hükme, içlerinde hiçbir sıkıntı duymaksızın, tam bir teslimiyetle boyun eğmedikçe iman etmiş olmazlar." (Nisâ 4/65).

Dolayısıyla babasının boşama talebini reddeden İbn Ömer'in kafasinda, Hz. Peygamberin talebini yerine getirmesi gerektiğine dair bir netlik olduğu söylenebilir. O, Resûlullâh'a (s.a.s.) bir peygamber olarak itaat edilmesi gerektiğini bildiği gibi, bir kâdı ve hakem olarak da verdiği hükümlere itaat edilmesi gerektiğini bilmektedir. Bu nedenle de babasını dahi dinlemediği böylesi önemli bir hususta Resûlullah'ın (s.a.s.) bir hakem olarak verdiğine inandığımız talebini gönül rahatlığıyla kabul etmiştir.

\section{Sonuç}

Hz. Peygamber'in İbn Ömer'e "eşini boşa” dediği rivayet sened ve metin açısından problemli görülmemektedir. Rivayet, sened cihetiyle hasen diyebileceğimiz bir hadistir. Âlimlerin bu konuda farklı görüşleri olsa da kanaatimizce bu, Resûlullah'ın (s.a.s.) İbn Ömer (r.a.) ile ilgili verdiği hâkimlik ve kâdılık sıfatına müteallik bir beyanıdır.

Hz. Peygamber'in hâkimlik ve kadılık sıfatıyla verdiği kararlar ve bu bağlamda ondan sadır olan rivayetler ise genel teşrî’ hükmünde değildir. Bu itibarla Hz. Peygamberin bazı insanlar hakkında verdiği hükümlerine bakıp aynı hükmü genel geçer hüküm olarak kabul etmek doğru değildir. Bu nedenle Hz. Peygamberden sadır olan tasarruflarının hangi cihetten olduğunu doğru tespit etmek gerekir. Aksi durumda birçok hadisin yanlış anlaşılması kaçınılmazdır.

İdrâc ve mana ile rivayetten kaynaklanan ravî tasarruflarının bazen hadislerin doğru anlaşılmasına olumsuz etki ettiği dikkate alınmalı, bir hadis hakkında doğru bir sonuca varmak için tüm sahih kaynaklardaki metinleri göz önünde bulundurulmalıdır. Bunun yanında ilgili ayetler, sahih hadisler, İslam'ın temel ilkeleri ve âlimlerin hadisi anlama şekilleri de dikkate alınmalıdır. Bütün bu hususlar dikkate alındığında İbn Ömer'le ilgili olan bu hadisin, anne babaya itaat bağlamından ziyade Hz. Peygamber'in bir devlet kâdısı olarak meseleleri çözme cihetiyle ilgili olduğu anlaşılmaktadir.

Netice olarak bu ve benzeri hadisleri delil göstererek özellikle boşama konusunda anne babaya itaatin gerekli veya müstahab olduğunu söylemek isabetli değildir.

\section{Kaynakça}

'Itr, N. (1997). Menhecu'n-Nakd fì 'ulûmi'l-hadîs. Dımaşk: Dâru'l-Fikr.

Abd b. Hümeyd, E. (1988). el-Muntehab min Müsnedi 'Abd b. Humeyd. Kahire: 'Âlemü'l-Kütüb.

Abdülbakî, M. F. (1950). el-Mu'cemü'l-Müfehres li Elfâzi'lKur'ani'l-Kerîm. tlk Md. Kahire: Müessesetü'r-risâle.

Acar, H. İ. (2010). İslam Ansiklopedisi. Talâk Md, Cilt: 39. İstanbul: TDV Yayınları.

Ahmed b. Hanbel, E. (1999). Müsnedü'l-İmâm Ahmed bin Hanbel. Beyrut: Müessesetü'r-Risâle.

Alâu'dîn, A. (1988). Nihâyetu'l-ĭğtibât. Kahire: Dâru'lHadîs.

Alî el-Kârî, A. (2002). Mirkâtu'l-Mefâtîh. Beyrut: Dârü'lFikr.

Bakan, T. (1983). Ashâbın Adaleti. Doktora Tezi. Erzurum: Atatürk Üniversitesi.

Beyhakî, E. (2003). Sünenü'l-Kübrâ. Beyrut: Dâru'lKutubi'l-İlmiyye.

Bezzâr, E. (2005). el-Behru'z-Zehhâr/Müsned. Medine: Mektebetü'l-İlmi ve'l-Hikem.

Buhârî, E. (1986). et-Târîhu's-Să̌̂̀r/Târîhu'l-Evsat. Beyrut: Dârü'l-Ma'rife.

Buhârî, E. (1986). Târîhu'l-Kebîr. Beyrut: Dâru'l-Kutubi'l'İlmiyye.

Buhârî, E. (1993). el-Câmiu's-sahîh. Beyrut: Dâru İbn Kesîr.

Coşkun, S. (2011). Hadise Bütüncül Bakış. İstanbul: İfav.

Dalgın, N. (2009). Günümüzdeki Tartışmalı Dînî Konular. İstanbul: Ensâr Yayınları.

Ebû Dâvud, S. (ty). Sünenu Ebî Dâvud, Beyrut: Dârü'lKütübi'l-'Arâbî.

Ed-Dihlevî, Ş. (2005). Huccetullâhi'l-Bâliğa. Beyrut: Dârü'l-Cîl.

el-'İclî, E. (ty). Ma'rifetu's-Sıkât. Kahire: Matbaatu'lMedenî.

El-Bağavî, H. (1983). Şerhu's-Sünne. Beyrut: elMektebetü'l-İslâmî.

el-Bağdâdî, H. (1358). el-Kifâye fì 'Ilmi'r-Rivâye. Haydarabad: Dâiretu'l-Me arifi'l-Osmaniyye.

el-Cuzecânî, İ. (1990). Ahvâlu'r-Ricâl. Pakistan: Hadith Academy.

el-Karrâfî, Ş. (2003). el-Furûk. Beyrut: Müessesetü’r-Risâle.

El-Kelâbâzî, A. (1987). Ricâlu Sahîhi'l-Buhârî. Beyrut: Dârü'l-Ma'rife. 
el-Minşâvî, M. (1996). Kâmûsu Mustalahâti'l-Hadîs enNebevî. Kahire: Dâru'l-Fazîla.

el-Mizzî, C. (1994). Tehzibu'l-Kemal fi Esmai'l-Ricâl. Beyrut: Müessesetu'r-Risâle.

el-Münâvî, M. (1972). Feydu'l-Kadîr. Beyrut: Dârü'lMa'rife.

en-Nesâî, A. (2001). Sünenü'l-Kübrâ. Beyrut: Müessesetu'rRisâle.

en-Nevevî, Y. (ty). Tehzîbü'l-Esmâi ve'l-Luğât. Beyrut: Dârü'l-Kütübi'l-İlmiyye.

Erdoğan, M. (2010). Flkıh ve Hukuk Terimleri. İstanbul: Ensar Kitap.

Eroğlu, S. (1986). Talâk hakkında Kur'an-1 Kerim'in Genel Tutumu. Ankara Üniversitesi İlahiyat Fakültesi Dergisi, (28), 159-165.

es-Seyyîd Sâbık, E. (1987). Fıkhu's-Sünne. Beyrut: Dâru'lKutubi'l-Arabî.

eş-Şafiî, M. (ty). Müsnedü'ş-Şâfi 'î. Beyrut: Dârü'l-Kütübi'lİlmiyye.

et-Taberânî, S. (1983). el-Mu'cemü'l-Kebîr. Musul: Mektebetu'l-'Ulûm.

et-Tayâlisî, E. (1999). Müsnedu Ebî Dâvud et-Tayâlisî. Mısır: Dâru Hecer.

Gazâlî, E. (ty). İhyâu 'Ulûmi'd-dîn. Kahire: Dârü'ş-Şa'b.

Hâkim en-Neysâbûrî, E. (ty). el-Müstedrek 'Ale's-Sahîhayn. Beyrut: Dârü'l-Ma'rife.

Heysemî, N. (1994). Mecme'u'z-Zevâid ve Menbe'u'lFevâid. Beyrut: Dârü'l-Fikr.

Işık, M. (2008). Ebû Dâvud Et-Tayâlisî ve Müsned'i. Yüksek Lisans Tezi, Adana: Çukurova Üniversitesi.

İbn Ca'd, E. (1985). Müsned. Kuveyt: Mektebetü'l-Fellâh.

İbn Ebî Hâtım, M. (1952). el-Cerhu ve’t-Ta'dîl. Beyrut: Dârü'l-Kütübi'l-İlmiyye.

İbn Ebî Şeybe, E. (2006). Musannef. Beyrut: Müessesetü 'Ulûmi'l-Kur'an/Dâru Kurtuba.

İbn Hacer, E. (ty). Tabakâtu'l-Müdellisîn. Ürdün: Mektebetü'l-Menâr.

İbn Hacer, E. (1379). Fethu'l-Bârî Şerhu Sahîhi'l-Buhârî. Beyrut: Dârü'l-Ma'rifa.

İbn Hacer, E. (1991). Takrîbu't-Tehzîb. Sûriye: Dârü'rRaşîd.

İbn Hacer, E. (1995). Tehzîbu't-Tehzîb. Beyrut: Müessesetü'r-Risâle.

İbn Hazm, E. (ty). el-ïhkâm fî Usûli'l-Ahkâm. Beyrut: Dârü'l-Afâk el-Cedîde.

İbn Hibbân, M. (1975). es-Slkât. Beyrut: Dârü'l-Fikr.

İbn Hibbân, M. (1992). el-Mecruhîn. Beyrut: Dârü'lMa'rifa.
İbn Hibbân, M. (1993). Sahîhu İbn Hibbân bitertîbi İbn Belbân. Beyrût: Muessesetü'r-Risâle.

İbn Kayyım el-Cevziyye, Ş. (1994). Zâdü'l-Me'âd fì Hedyi Hayri'l- 'Íbâd. Beyrut: Müessesetü'r-Risâle.

İbn Kuteybe, A. (1999). Te'vîlu Muhttelifi'l-Hadîs. Beyrut: Mektebetü'l-İslâmî.

İbn Mâce, M. (ty). Sünenu İbn Mâce. Beyrut: Dârü'l-fikr.

İbn Teymiye, A. (1987). el-Fetâvâ el-Kubrâ. Beyrut: Dârü'lKütübi'l-İlmiyye.

İbrahim M. \& vd. (2004). Mu'cemu'l-Vesît. Misır: Dârü'dDa've.

Kandemir, M. Y. (1988). Islam Ansiklopedisi. Abdullah b. Ömer b. Hattâb Md, Cilt: 1. İstanbul: TDV Yayınları.

Karadâvî, Y. (2008). Sünneti Anlamada Yöntem. İstanbul: Nida Yayınları.

Karadâvî, Y. (2015). Bilgi ve Medeniyet Kaynă̆ı Sünnet. İstanbul: Nida Yayıncılık.

Kastalânî, E. Ş. (1323). İşâdu's-Sârî. Mısır: Matbaatü'lEmiriyye.

Kırbaşoğlu, M. H. (1991). Kadın Konusunda Kur'an'a Yöneltilen Başlıca Eleştiriler. İslami Araştırmalar Dergisi, 5(4), 271-283.

Mâlik b. Enes, E. (2004). el-Muvatta. Ebû Zabiy: Müessesetu Zâyd b. Sultân.

Müslim, M. (ty). Sahîhu Müslim. Beyrut: Dâru İhyâi’tTurâsi'l-Arabî.

Nâsıf, M. A. (1962). et-Tâcu'l-Câmi'u li'l-Usûl. İstanbul: Mektebetu Pâmuk.

Tahâvî, (1994). Şerhu Muşkilu'l-Âsâr. Beyrut: Müessesetü'r-Risâle.

Tirmizî, M. (1962). el-Câmi'u's-Sahîh Sünenü't-Tirmizî. Beyrut: Dâru İhyâi't-Türâsi'-Arabî.

Tirmizî, M. (ty). el-Câmi'u's-Sahîh Sünenü't-Tirmizî. Beyrut: Dâru İhyâi't-Türâsi'-Arabî.

Wensinck, (1936). el-Mu'cemü'l-Müfehres li Elfâzi'lHadîsi'n-Nebevî. tlk Md, Leiden:

Zehebî, Ş. (1992). el-Kâşiff fì Ma'rifeti men lehu Rivayetun fì'l-Kutubi's-Sitte. Cidde: Dârü'l-Kıble.

Zehebî, Ş. (1998). Tezkiretü'l-Hüffâz. Beyrut: Dârü'lKutubi'l-İlmiyye.

Zehebî, Ş. (ty). el-Muğnî fi'd-Duafâ. thk. Nûreddîn 'Atr, Katar: İdâretü İhyâi Turâsi'l-İslâmî.

Zehebî, Ş. (1425). Men Tukullime Fîh. Medine: Mektebetu Melik Fehd.

Zehebî, Ş. (1992). er-Ruvâtu's-Sıkât. Beyrut: Dârü'l-Beşâir.

Zehebî, Ş. (1406). Mîzânu'l-İ'tidâl. Beyrut: Dârü'l-Ma'rife. 